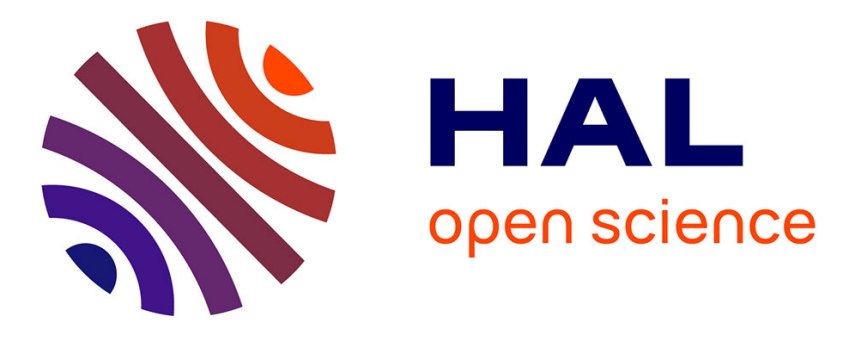

\title{
High ionic conductivity in oxygen-deficient Ti-substituted sodium niobates and the key role of structural features
}

Guillaume Gouget, Mathieu Duttine, U-Chan Chung, Sébastien Fourcade, Fabrice Mauvy, Marc-David Braida, Thierry Le Mercier, Alain Demourgues

\section{To cite this version:}

Guillaume Gouget, Mathieu Duttine, U-Chan Chung, Sébastien Fourcade, Fabrice Mauvy, et al.. High ionic conductivity in oxygen-deficient Ti-substituted sodium niobates and the key role of structural features. Chemistry of Materials, 2019, 31 (8), pp.2828-2841. 10.1021/acs.chemmater.8b05292 . hal02115747

\section{HAL Id: hal-02115747 \\ https://hal.science/hal-02115747}

Submitted on 30 Apr 2019

HAL is a multi-disciplinary open access archive for the deposit and dissemination of scientific research documents, whether they are published or not. The documents may come from teaching and research institutions in France or abroad, or from public or private research centers.
L'archive ouverte pluridisciplinaire HAL, est destinée au dépôt et à la diffusion de documents scientifiques de niveau recherche, publiés ou non, émanant des établissements d'enseignement et de recherche français ou étrangers, des laboratoires publics ou privés. 


\title{
High ionic conductivity in oxygen-deficient Ti-substituted sodium ni- obates and the key role of structural features
}

\author{
Guillaume Gouget ${ }^{\mathrm{a}, \dagger}{ }^{\dagger},{ }^{*}$, Mathieu Duttine ${ }^{\mathrm{a}}$, U-Chan Chung ${ }^{\mathrm{a}}$, Sébastien Fourcade ${ }^{\mathrm{a}}$, Fabrice Mauvy ${ }^{\mathrm{a}}$, Marc- \\ David Braida $^{\mathrm{b}}$, Thierry Le Mercier ${ }^{\mathrm{b}}$ and Alain Demourgues ${ }^{\mathrm{a}, *}$. \\ ${ }^{\text {a }}$ CNRS, Université de Bordeaux, ICMCB, UMR 5026, 87 Avenue du Dr. Albert Schweitzer, 33608 Pessac Cedex, France \\ ${ }^{\mathrm{b}}$ Solvay, Research and Innovation Center Paris, F-93308, Aubervilliers, France
}

\begin{abstract}
NaNb}_{1-\mathrm{x}} \mathrm{Ti}_{\mathrm{x}} \mathrm{O}_{3-0.5 \mathrm{x}}(0<\mathrm{x} \leq 0.15)$ compounds were prepared using a two-step synthesis involving a hydrothermal route at $\mathrm{T}=200{ }^{\circ} \mathrm{C}$ in an autoclave followed by heat treatments under air or reductive conditions. Rietveld structural refinements from $\mathrm{X}$ ray diffraction data combined with ${ }^{23} \mathrm{Na}$ and ${ }^{93} \mathrm{Nb}$ nuclear magnetic resonance evidenced the formation of new complex oxides crystallizing in the $\mathrm{P} 2{ }_{1}$ ma space group. Ti substitution for $\mathrm{Nb}$ atoms contributes to stabilize the acentric polymorph rather than the well-known thermodynamically stabilized network (Pbma space group) of sodium niobate. Taking into account the competitive bonds sequences $\mathrm{Na1}(2)-\mathrm{O} 1(2)-\mathrm{Nb}-\mathrm{O} 3(4)$, the large variation of Na1-O1 and Na2-O2 bond lengths after Ti substitution leads to reduce the $\mathrm{Nb} / \mathrm{Ti}-\mathrm{O} 1$ and $\mathrm{Nb} / \mathrm{Ti}-\mathrm{O} 2$ apical distortion (elongation in one direction) and consequently to exalt the distortion in the equatorial plane. Then, the transition metal crystal-field splitting increases as well as the second-order Jahn-Teller effect and the optical band gap red-shifts to visible range starting with low Ti content. Two phase-transition sequences at moderated temperature are characterized by the relaxation of the perovskite framework with various $\left[\mathrm{Nb}(\mathrm{Ti}) \mathrm{O}_{6}\right]$ octahedral distortion and tilt modes: from the polar orthorhombic P $2{ }_{1}$ ma phase to the centrosymmetric orthorhombic $\mathrm{Cmcm}$ network above $\mathrm{T}=300{ }^{\circ} \mathrm{C}$ and then to the ideal cubic perovskite structure above $\mathrm{T}=600^{\circ} \mathrm{C}$. The pronounced decrease of phase transition temperature with $\mathrm{Ti}$ substitution, especially from $\mathrm{P} 2{ }_{1} \mathrm{ma}$ to $\mathrm{Cmcm}$, was correlated to the almost identical stabilities of the two Na sites and the four oxygen positions in $\mathrm{P} 2{ }_{1}$ ma symmetry but also to larger distortion of the transition metal polyhedron enhancing the oxygen mobility. Moreover, the high ionic conductivity of oxygen-deficient $\mathrm{NaNb}_{1-\mathrm{x}} \mathrm{Ti}_{\mathrm{x}} \mathrm{O}_{3-0.5 \mathrm{x}}$ was evidenced for the first time between 300 and $700{ }^{\circ} \mathrm{C}\left(\sigma_{\text {ion }}\left(\mathrm{T}=300{ }^{\circ} \mathrm{C}\right)\right.$

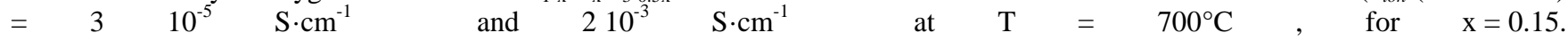

\section{INTRODUCTION}

Perovskite-related phases with non-stoichiometry phenomena and unusual electronic properties have been extensively investigated in numerous applications and fundamental works. ${ }^{1}$ Their diversity in term of composition and physical properties has been extensively described as well as the various distortions from the ideal cubic symmetry with tilted polyhedra. Moreover, even more complex organizations occur from 3D networks to 2D layers, such as Ruddlesden-Popper phases with alternating perovskite and rock-salt type slabs. ${ }^{2}$ The search for new perovskites with specific frameworks associated to octahedral tilt mode and phase transitions with polar structures represents a great challenge in the field of ferroelectricity. ${ }^{3,4}$ Systematic investigations are now being performed on different structural families in order to identify all potential candidates for such application. ${ }^{5}$

In the case of solid oxide fuel cells and solar-to-fuel conversion, ${ }^{6}$ high mobility of oxygen anions related to the ionic conductivity is one of the key parameters for an efficient electrolyte material and oxygen reservoir, respectively. There are several recent discoveries of perovskite-derived structures with high ionic conductivities associated to oxygen species below $700{ }^{\circ} \mathrm{C}$, paving the way towards relatively low temperature applications. ${ }^{7-9}$ To achieve high oxide ion conduction, oxygen vacancies can be created through the partial substitution of low valence cation for the 6-fold coordinated cations (B site) in the perovskite network, ${ }^{10}$ a strategy that can be adapted to other structures. ${ }^{11}$ In perovskite-related structures, the ionic conductivity can be also driven by polarizable cations 12-fold coordinated to oxygens (A site), ${ }^{12-15}$ especially when the A site is partially vacant, again due to the stabilization of low valent cation in B site. ${ }^{16}$ From a theoretical point of view, the stability of the perovskite type is governed by the ionic radii and the well-known Goldschmidt tolerance factor. ${ }^{17}$ Taking into account the ionic radii ratio with cations in $\mathrm{A}$ and $\mathrm{B}$ sites, for $\mathrm{r}\left(\mathrm{A}^{\mathrm{n}+}\right) / \mathrm{r}\left(\mathrm{B}^{\mathrm{m+}}\right)>1.80$, the $3 \mathrm{D}$ or $2 \mathrm{D}$ perovskite network is generally stabilized whereas the pyrochlore structure is obtained for $1.46<\mathrm{r}\left(\mathrm{A}^{\mathrm{n}+}\right) / \mathrm{r}\left(\mathrm{B}^{\mathrm{m}+}\right)<1.80$ and finally the fluorite framework is favored for $r\left(A^{n+}\right) / r\left(B^{m+}\right)<1.46$. The introduction of vacancies at the A site promotes cation ordering and the formation of superstructures evidenced, for instance, in tetragonal or hexagonal tungsten bronzes. ${ }^{18,19}$ Supercells are required to give a pertinent crystallographic description of the structure and cationic conduction properties strongly depend on the pathways available for the cations into the framework. ${ }^{20}$ The perovskite, the pyrochlore and the fluorite-type structures are also among the networks which exhibit the best oxygen mobility associated with the easy creation of oxygen vacancies. Correlations between $\mathrm{O}$ deficiency, structural features and conduction properties is perfectly exemplified with the recently discovered structure of $\mathrm{Ba}_{3} \mathrm{MoNbO}_{8.5}$ complex oxide. ${ }^{9}$ Structural reorganization is evidenced upon heating, favoring the occupancy of $\mathrm{Mo}^{6+} / \mathrm{Nb}^{5+}$ cations in tetrahedral sites rather than in octahedral ones. Ac- 
cordingly, oxygen site occupancies are impacted, leading to an increase in oxygen mobility over $500{ }^{\circ} \mathrm{C}$, as observed through the change in associated activation processes.

Phase transitions of sodium niobates have been extensively studied and the $\left[\mathrm{NbO}_{6}\right]$ octahedral tilt modes and distortion are strongly correlated to the second order Jahn-Teller distortion of $\mathrm{Nb}^{5+}\left(4 \mathrm{~d}^{0}\right){ }^{21-25}$ As considered above, the symmetry of $\mathrm{A}, \mathrm{B}$ and $\mathrm{O}$ sites for atoms in perovskite-related networks are a key feature to modify the structure, to induce distortions, pathways and orderings that are all crucial parameters to improve ionic conductivity. For instance, elongated or flattened octahedral B site can favor the oxygen mobility. High oxygen ionic conductivity has been reported in several other perovskites, ${ }^{7-10}$ but ionic conduction properties of Ti-substituted sodium niobates have never been investigated.

$\mathrm{Ti}^{4+}$ in 6-fold coordination $(\mathrm{r}=0.605 \AA)$ can partially substitute for $\mathrm{Nb}^{5+}$ with identical coordination number $(\mathrm{r}=0.635 \AA)$, due to similar ionic radii. ${ }^{26}$ The $\mathrm{NaNb}_{1-\mathrm{x}} \mathrm{Ti}_{\mathrm{x}} \mathrm{O}_{3-0.5 \mathrm{x}}$, with $0<\mathrm{x} \leq 0.20$, crystal structure was described by $\mathrm{Xu}$ et al. as an isomorph of the well-known room temperature phase of $\mathrm{NaNbO}_{3}$ ( $\mathrm{x}=0$, space group Pbma) from powder X-ray diffraction (XRD) and neutron diffraction investigations. ${ }^{27} \mathrm{Ti}$ bearing sodium niobates were synthesized via a sol-gel technique followed by high temperature annealing under air at 900 ${ }^{\circ} \mathrm{C}$ during $15 \mathrm{~h}$. Ti-substitution was shown to relax the perovskite distortion, in agreement with the Goldschmidt tolerance factor close to $1,{ }^{28}$ but it destabilizes the structure in term of free energy, due to increasing O-deficiency and unfavorable $\mathrm{Nb}-\mathrm{O}-\mathrm{Ti}$ bridges. Since then, $\mathrm{NaNb}_{1-\mathrm{x}} \mathrm{Ti}_{\mathrm{x}} \mathrm{O}_{3-0.5 \mathrm{x}}$ structures had not been investigated anymore.

A second polymorph of $\mathrm{NaNbO}_{3}$ is also known to exist at ambient conditions, adopting the $\mathrm{P} 2{ }_{1}$ ma space group since a study by Glazer and co-workers, 45 years ago. ${ }^{21}$ This phase named $Q$ was never obtained pure until very recently, ${ }^{29}$ due to the thermodynamically favored $\mathrm{P}$ phase that can be described in the Pbma space group. Hydrothermal conditions coupled to mild annealing conditions $\left(600{ }^{\circ} \mathrm{C}, 6 \mathrm{~h}\right)$ were shown to kinetically favor the $\mathrm{Q}$ phase. Besides these two room temperature polymorphs, $\mathrm{NaNbO}_{3}$ undergoes five consecutive phasetransitions versus temperature $(\mathrm{T}>\mathrm{RT})$, in addition to one rhombohedral transition at low $\mathrm{T}(\mathrm{T}<\mathrm{RT}) .{ }^{24}$ Discussions on this complex thermal behavior is still going on nowadays with in-depth structural and physical studies. ${ }^{25,30}$ It is noteworthy that the increase in temperature is accompanied with a general increase in the crystallographic symmetry, leading to the ideal cubic symmetry above $670{ }^{\circ} \mathrm{C}$. Both RT phases share structural similarities, with periodical octahedra tilting by comparison with the cubic structure (space group Pm-3m). As a consequence, structural characterization by powder-XRD requires much attention on specific minor peaks to avoid misinterpretation. Differentiating local distortions of $\mathrm{Na}$ environments by ${ }^{23} \mathrm{Na}$ nuclear magnetic resonance (NMR) was shown to allow unambiguous distinction between the RT polymorphs, depending on the synthesis conditions. ${ }^{23}$ In this work, sol-gel route was chosen to yield the polar $\mathrm{NaNbO}_{3}$ in relatively good proportions. Taking into account that the symmetry is lower in space group $\mathrm{P} 2{ }_{1}$ ma than in Pbma with various cooperative octahedral tilt modes, the comparable stability of $\mathrm{Na} 1$ and $\mathrm{Na} 2$ sites in the polar phase contributes through competitive bonds to the larger distortion of $\left[\mathrm{NbO}_{6}\right]$ octahedra. ${ }^{29}$

Downsizing $\mathrm{NaNbO}_{3}$ affects the relative proportion of polymorphs. ${ }^{31,32}$ It recently attracted interest for size-induced fer- roelectric ${ }^{33-36}$ and photocatalytic ${ }^{37-40}$ properties, but also for piezoelectric $^{41}$ devices. Substituting potassium for sodium leads to $\mathrm{K}_{\mathrm{x}} \mathrm{Na}_{1-\mathrm{x}} \mathrm{NbO}_{3}$, which belongs to the most promising piezoelectrics for the replacement of the current industrial technologies based on hazardous lead titanates and zirconates. ${ }^{42,43}$ Polar phases can be stabilized as sodium cations are partly substituted for lithium $\left(\mathrm{Li}_{\mathrm{x}} \mathrm{Na}_{1-\mathrm{x}} \mathrm{NbO}_{3}\right)^{44}$ and also when fluorine substitutes partially oxygen $\left(\mathrm{KNaNbOF}_{5}\right)^{45,46}$ No Ti-substituted sodium niobate with a polar structure has ever been reported so far.

In the present work, the synthesis of $\mathrm{NaNb}_{1-\mathrm{x}} \mathrm{Ti}_{\mathrm{x}} \mathrm{O}_{3-0.5 \mathrm{x}}$, $0<\mathrm{x} \leq 0.20$ is reported, starting with hydrothermal conditions. Various times and temperatures of annealing under air were investigated to conclude on the relative stability of RT phases, especially concerning the occurrence of a phase crystalizing in the $\mathrm{P} 2{ }_{1}$ ma space group. The effect of Ti-substitution on the structural features and especially the $\mathrm{Na}-\mathrm{O}$ and $\mathrm{Nb} / \mathrm{Ti}-\mathrm{O}$ chemical bonding was investigated experimentally using powderXRD data (Rietveld) analysis, ${ }^{23} \mathrm{Na}$ and ${ }^{93} \mathrm{Nb}$ solid-state NMR, and diffuse reflectance in the UV-Visible range to evaluate the optical band gap variations in this series. The relative stability of atom sites was evaluated by Madelung potentials calculation based on an ionic model, considering local environments of punctual charges formed by neighboring atoms. As mentioned above, in the case of $\mathrm{NaNbO}_{3}, \mathrm{Na} 1$ and $\mathrm{Na} 2$ atomic positions play a key role to influence oxygen sites around the $\mathrm{Nb}^{5+}$ local sphere. In order to have a better view of atomic rearrangement after $\mathrm{Ti}$ substitution, we then focused on $\mathrm{Na}$ and $\mathrm{Nb}$ local environments to analyze the impact of $\mathrm{O}$ deficiency and the consequences on ionic mobility. The ionic conductivity of pellets sintered by Spark Plasma Sintering (SPS) was measured for $0 \leq \mathrm{x} \leq 0.15$ in the $300-700{ }^{\circ} \mathrm{C}$ range within which successive phase-transitions occur. The nature of mobile ions $\left(\mathrm{O}^{2-}\right.$ and/or $\left.\mathrm{Na}^{+}\right)$is also discussed. Finally, the ionic conductivity and mobility is correlated to the chemical composition and the structural features. Then, the ionic conductivity of specific compositions is compared with the best solid state electrolytes (oxygen ion mobility) used in solid oxide fuel cells, such as gadolinium-doped ceria or yttriastabilized zirconia.

\section{EXPERIMENTAL SECTION}

Synthesis. $1 \mathrm{~g}$ of $\mathrm{NaNb}_{1-\mathrm{x}} \mathrm{Ti}_{\mathrm{x}} \mathrm{O}_{3-0.5 \mathrm{x}}$ was prepared from $\mathrm{Nb}_{2} \mathrm{O}_{5}$ (99.99\%, Sigma-Aldrich) and $\mathrm{TiOCl}_{2}$ solution in hydrochloric solution $(\mathrm{d}=1.58, \%$ mas. $(\mathrm{Ti})=15$, Alfa Aesar $)$ in $20 \mathrm{~mL}$ of $\mathrm{NaOH} 6 \mathrm{M}$. Quantities of both $\mathrm{Nb}$ and Ti precursors (mg and $\mu \mathrm{L}$, respectively) were 810 and 0 for $\mathrm{x}=0,783$ and 62 for $\mathrm{x}=0.05,755$ and 125 for $\mathrm{x}=0.10,724$ and 194 for $\mathrm{x}=0.15$, 693 and 264 for $\mathrm{x}=0.20 . \mathrm{Nb}_{2} \mathrm{O}_{5}$ was dispersed in caustic soda prior to the addition of $\mathrm{TiOCl}_{2}$. The dispersions were heat treated in $\mathrm{P} 4744$ autoclaves (Parr) equipped with $45 \mathrm{~mL}$ Teflon vials, using a P330 oven (Nabertherm), at $200{ }^{\circ} \mathrm{C}$ during $24 \mathrm{~h}$, heating and cooling ramps of $2^{\circ} \mathrm{C} \cdot \mathrm{min}^{-1}$. The white sediment and supernatant were both transferred in a $200 \mathrm{~mL}$ centrifuge tube (Nalgene) and centrifuged (Sigma 3-30K apparatus) $15 \mathrm{~min}$ at $7 \mathrm{krpm}$. The supernatant was removed, the pellet was dispersed in ca. $100 \mathrm{~mL}$ of deionized water and the dispersion was centrifuged $15 \mathrm{~min}$ at $7 \mathrm{krpm}$. The separation, dispersion and centrifugation process was repeated once. Finally, the supernatant was removed and the pellet was dried at $80{ }^{\circ} \mathrm{C}$ over-night. Annealing treatments were performed under air in tubular ovens connected to a Eurotherm temperature 
controller with systematic $2{ }^{\circ} \mathrm{C} \cdot \mathrm{min}^{-1}$ heating and cooling ramps.

X-ray diffraction data were collected on a PANalytical X'Pert Pro powder diffractometer with Bragg-Brentano $\theta-\theta$ geometry. Samples were prepared from soften powder (particle size $<45 \mu \mathrm{m}$ ) flattened with the edge of a razor blade to avoid any preferential orientation. For the thermal studies, a Co $\mathrm{K} \alpha_{1} / \mathrm{K} \alpha_{2}$ radiation source was used, acceleration tension 40 $\mathrm{kV}$ and working current $50 \mathrm{~mA}, 15 \leq 2 \theta \leq 75^{\circ}$ with $0.017^{\circ}$ steps, counting time of $400 \mathrm{~s}$. Experiments were performed under helium (Air Liquide) using a HTK16 cell (Anton-Parr) with walls made of kapton. Each acquisition was separated by a heating ramp of $2{ }^{\circ} \mathrm{C} \cdot \mathrm{min}^{-1}$ followed by an equilibration time of $30 \mathrm{~min}$. Other experiments were performed with a $\mathrm{Cu}$ $\mathrm{K} \alpha_{1} / \mathrm{K}_{2}$ radiation source, acceleration tension $45 \mathrm{kV}$ and working current $40 \mathrm{~mA}, 8 \leq 2 \theta \leq 80^{\circ}$ with $0.017^{\circ}$ steps, counting time of $300 \mathrm{~s}$. Refinements were performed on JANA2006 software. ${ }^{47}$ Isotropic displacements parameters $\beta_{\text {iso }}$ were always maintained at 0.5 for $\mathrm{Nb}$ and 1 for $\mathrm{Na}$ and $\mathrm{O}$.

${ }^{23} \mathrm{Na}$ and ${ }^{93} \mathrm{Nb}$ nuclear magnetic resonance spectra were acquired at a 7.05 $\mathrm{T}$ static magnetic field (Larmor frequencies: 79.4 MHz and 73.5 MHz, respectively) under Magic Angle Spinning (MAS) conditions at a frequency of $30 \mathrm{kHz}$ with a $2.5 \mathrm{~mm}$ Bruker probe. A single short pulse $(\pi / 8)$ excitation of $1.5 \mu \mathrm{s}$ (RF field strength: ca. $166 \mathrm{kHz}$ ) and a recycling delay ranging from 2 to $10 \mathrm{~s}$ were used for ${ }^{23} \mathrm{Na} \mathrm{NMR}$ experiments, while a single pulse excitation of $2.2 \mu$ s (RF field strength: ca. $114 \mathrm{kHz}$ ) and a recycling delay of $0.2 \mathrm{~s}$ were selected for ${ }^{93} \mathrm{Nb}$ NMR experiments. Chemical shifts were calibrated according to a molar solution of $\mathrm{NaCl}\left(\delta\left({ }^{23} \mathrm{Na}\right)=0.0 \mathrm{ppm}\right)$ or a saturated solution of $\mathrm{NbCl}_{5} / \mathrm{CH}_{3} \mathrm{CN}\left(\delta\left({ }^{93} \mathrm{Nb}\right)=0.0 \mathrm{ppm}\right)$. Refinements of NMR parameters were performed with dmfit software. ${ }^{48}$

Diffuse reflectance spectra were recorded on powders at room temperature on a Carry-Varian 5000 using an integration sphere in the $200-800 \mathrm{~nm}$ range with $1 \mathrm{~nm}$ step. $\mathrm{MgO}$ powder was used as a white reference.

Spark Plasma Sintering experiments were performed on a 515S Syntex (Dr. Sinter) apparatus. $0.8 \mathrm{~g}$ of $\mathrm{NaNb}_{1-\mathrm{x}} \mathrm{Ti}_{\mathrm{x}} \mathrm{O}_{3-0.5 \mathrm{x}}$ from hydrothermal synthesis was introduced in a graphite dye (10 $\mathrm{mm}$ in diameter) covered with Papyex. A dynamic vacuum at ca. $10 \mathrm{~Pa}$ was maintained during the experiments. Uniaxial pressure of $7.9 \mathrm{kN}(100 \mathrm{MPa})$ was applied in $1 \mathrm{~min}$ prior to heating ramp at $50{ }^{\circ} \mathrm{C} \cdot \mathrm{min}^{-1}$ up to $900{ }^{\circ} \mathrm{C}(\mathrm{x}=0)$ or $800{ }^{\circ} \mathrm{C}$ $(\mathrm{x}=0.05,0.10$ and 0.15$)$. The sample was maintained $5 \mathrm{~min}$ at the dwell temperature and then left to cool below $100{ }^{\circ} \mathrm{C}$ in vacuum. The pressure was released $1 \mathrm{~min}$ after the dwell ended, from 7,9 to $0.5 \mathrm{kN}$ (minimal charge) in $3 \mathrm{~min}$. A polishing step was required to remove the carbon layer from Papyex, using abrasive $\mathrm{SiC}$ sandpapers with increasing grit sizes from 120 to 2400 . For annealing under air, dense pellets were heated in a P330 oven (Nabertherm) from RT to $800{ }^{\circ} \mathrm{C}$ with a rate of $0.75^{\circ} \mathrm{C} \cdot \mathrm{min}^{-1}$. Temperature was maintained at $800{ }^{\circ} \mathrm{C}$ during $12 \mathrm{~h}$ and then cooled to RT with a $0.75{ }^{\circ} \mathrm{C} \cdot \mathrm{min}^{-1}$ rate. Geometrical densities were calculated considering the pellets as cylinders with dimensions measured with a precision caliper. In this condition of SPS treatment, the density of niobiates is superior or equal to $92 \%$ whereas only density of $60 \%$ is reached after conventional sintering. SEM analysis of crushed pellets of these niobiates reveal grain sizes around $1 \mu \mathrm{m}$. Furthermore SEM-EDX analysis of crushed pellets allow confirming the $\mathrm{Na} /(\mathrm{Nb}+\mathrm{Ti})$ and $\mathrm{Nb} / \mathrm{Ti}$ molar ratios.
Complex impedance spectroscopy. A two electrodes symmetrical cell was used for Electrochemical Impedance Spectroscopy (EIS) measurements, using an Autolab PGSTAT20 Frequency Response Analyser. Signal of $200 \mathrm{mV}$ amplitude were applied in the $100 \mathrm{mHz}^{-1}-1 \mathrm{MHz}$ frequency range, 10 steps per decade. A thin film of metallic gold electrodes was deposited on both sides of the pellets by sputtering in partial argon atmosphere during $15 \mathrm{~min}$ to achieve homogenous compact gold film. Nyquist diagrams were recorded from $900{ }^{\circ} \mathrm{C}$ to $270{ }^{\circ} \mathrm{C}$ under air. Equilibrium time (at least 1 hour) has been respected before each measurement during the cooling thermal cycle in order to achieve ready state conditions. The impedance data were analyzed using ZView 2 software of Scribner Associate Inc. Each EIS diagram was fitted using an equivalent circuit consisting of resistances and constant phase elements in parallel. Specific sizes of each sample were taken into account. Some semi-circle signals were not sampled enough in the frequency range to be efficiently fitted this way. In this case, the resistance was considered as the $Z$ ' value where $\mid Z$ ' $\mid$ is minimized.

\section{RESULTS AND DISCUSSION}

Ti-substituted sodium niobates in the $\mathbf{P 2}{ }_{1}$ ma structure. Sodium niobium titanium oxides were obtained by hydrothermal synthesis at $200{ }^{\circ} \mathrm{C}$ during $24 \mathrm{~h}$, starting from niobium oxide and titanium oxychloride acidic solution added in caustic soda $\left(6 \mathrm{~mol} \cdot \mathrm{L}^{-1}\right)$. These conditions were adapted from the hydrothermal route developed for the synthesis of potassium and sodium niobates. ${ }^{49}$ Excess of dissolved sodium species was removed after several washing steps using deionized water. Figure 1 displays the X-ray diffraction (XRD) patterns of powders with various initial $\mathrm{Ti}: \mathrm{Nb}+\mathrm{Ti}$ atomic ratio (0 to 20 $\%)$ and Rietveld refinements of structures described in the Pbma space group, as described in the litterature. ${ }^{27}$ For $\mathrm{x}=0$, the structural refinement leads to a good agreement with the experimental pattern, especially in the key range $35.5 \leq 2 \theta \leq$ $44.5^{\circ}$. This interval has been previously demonstrated to be of prime importance to differentiate the various polymorphs of $\mathrm{NaNbO}_{3}{ }^{23,29}$
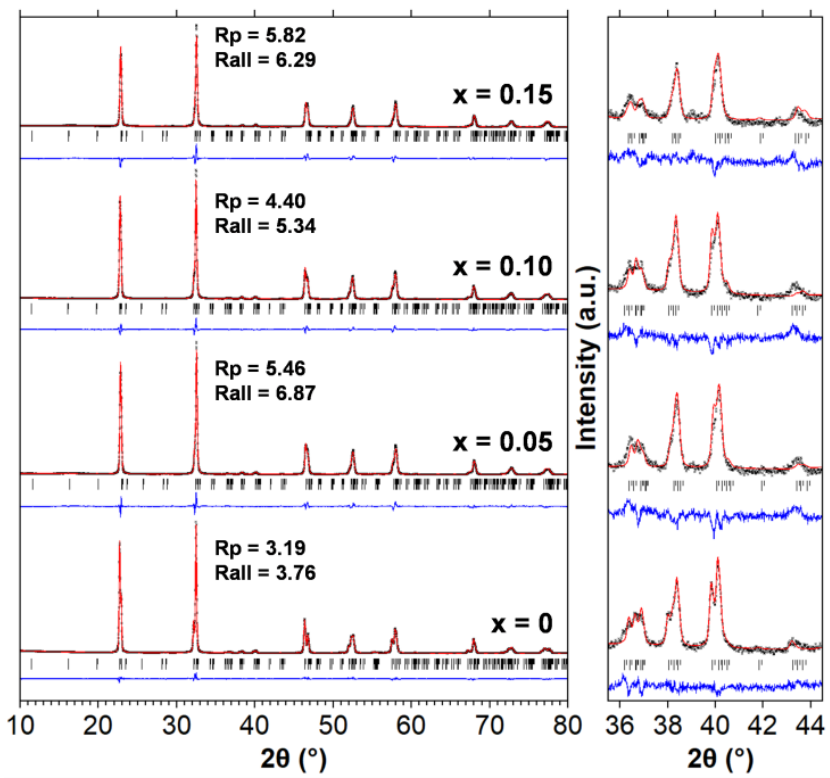

Figure 1. Powder-XRD experimental data (black crosses) and calculated patterns (red lines) from Rietveld structural refinements of $\mathrm{NaNb}_{1-\mathrm{x}} \mathrm{Ti}_{\mathrm{x}} \mathrm{O}_{3-0.5 \mathrm{x}}, 0 \leq \mathrm{x} \leq 0.15$ synthetized in hydro- 
thermal conditions. Rietveld refinements were performed considering the Pbma space group. Blue lines represent the difference between observed and calculated data.

Regarding the reliability factors and the difference between experimental and calculated patterns, the Rietveld refinements for $\mathrm{Ti}$ substituted compounds are overall satisfactory and in good agreement with $\mathrm{Xu}$ et al. ${ }^{27}$ However, the calculated intensity of some peaks, e.g. around $2 \theta=43.5^{\circ}$, does not perfectly match with the experimental data. Additional distorted perovskite-related structures should be taken into account to fully explain the observed XRD diagram. From this first XRD analysis, the Ti-substituted sodium niobates synthetized by hydrothermal route are crystallizing mainly but not exclusively in the Pbma space group. Additional heat treatments under air were then investigated to obtain pure phases. The first annealing treatment was operated at $600{ }^{\circ} \mathrm{C}$ during $6 \mathrm{~h}$ with heating and cooling ramps of $2{ }^{\circ} \mathrm{C} \cdot \mathrm{min}^{-1}$. For all Ti contents, powder-XRD patterns are shown in Figure 2.

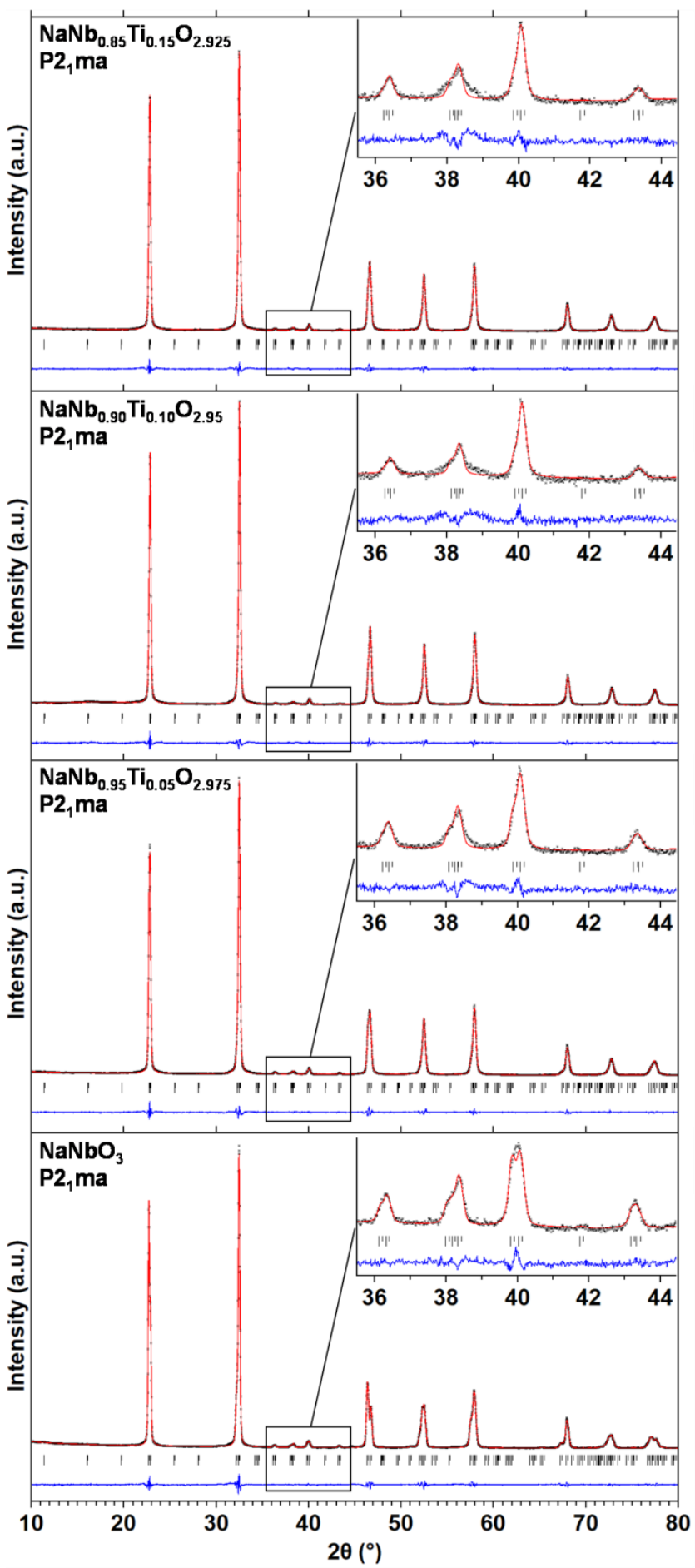

Figure 2. Full-pattern profile macthing of $\mathrm{NaNb}_{1-\mathrm{x}} \mathrm{Ti}_{\mathrm{x}} \mathrm{O}_{3-0.5 \mathrm{x}}$ $(0 \leq \mathrm{x} \leq 0.15)$ XRD patterns after annealing during $6 \mathrm{~h}$ at $600{ }^{\circ} \mathrm{C}$. (black crosses) experimental data, (red lines) calculated patterns considering the $\mathrm{P} 2{ }_{1}$ ma space group and (blue lines) difference between observed and calculated data.

Here, structural hypothesis in the polar $\mathrm{P} 2{ }_{1}$ ma space group is the most convenient to fit perfectly the experimental data, using full pattern profile matching. Compared to XRD data before heat treatment (Figure 1), the most significant change is the sharpening of the peak family at around $36.4^{\circ}$ thanks to phase transition from Pbma to $\mathrm{P} 2{ }_{1}$ ma space group (b unit cell parameter divided by 2). Indeed, inter-reticular planes (hkl) with odd $\mathrm{k}$ Miller indices in Pbma space group have no equiv- 
alent in the $\mathrm{P} 2{ }_{1}$ ma space group. To our knowledge, this is the first evidence of $\mathrm{NaNb}_{1-\mathrm{x}} \mathrm{Ti}_{\mathrm{x}} \mathrm{O}_{3-0.5 \mathrm{x}}(\mathrm{x}=0.05,0.10,0.15)$ crystallizing in this space group. When $\mathrm{x}$ increases, broadening of the XRD lines at around $2 \theta=38.1^{\circ}$ is observed experimentally as compared to the calculated pattern. This unexpected feature is attributed to poor crystallinity. Although atomic positions could not be refined at this stage, the effect of $\mathrm{Ti}$ substitution for $\mathrm{Nb}$ on local atomic organization was studied (i) indirectly by the variation of the unit cell parameter and (ii) directly by ${ }^{23} \mathrm{Na}$ and ${ }^{93} \mathrm{Nb}$ solid state NMR.

Unit-cell parameters and volume of Ti-doped sodium niobates deduced from the full-pattern profile matching are reported in Table 1 , considering the $\mathrm{P} 2{ }_{1}$ ma structural hypothesis. The volume linearly decreases with $\mathrm{Ti}$ content. This is consistent with smaller $\mathrm{Ti}^{4+}$ (ionic radii $\mathrm{r}\left(\mathrm{Ti}^{4+}[\mathrm{VI}]\right)=0.605 \AA$ ) substituting for $\mathrm{Nb}^{5+}\left(\mathrm{r}\left(\mathrm{Nb}^{5+}[\mathrm{VI}]\right)=0.635 \AA\right) .{ }^{26}$ It is noteworthy that a and $\mathrm{c}$ parameters decrease with $\mathrm{x}$ rate and tend to asymptotic values whereas the $b$ parameter increases for the lowest Ti rate $(\mathrm{x}=0.05)$ and then remains constant. The Ti substitution and the occurrence of oxygen vacancies should thus correspond to an elongation of the $\left[\mathrm{NbO}_{6}\right]$ octahedra along $\mathrm{b}$ axis and $\mathrm{a}$ reduction of $\mathrm{Nb}-\mathrm{O}$ bond distances in the equatorial planes. More specifically, between $\mathrm{NaNbO}_{3}$ and $\mathrm{NaNb}_{0.95} \mathrm{Ti}_{0.05} \mathrm{O}_{2.975}$, the stabilization of first $\mathrm{O}^{2-}$ vacancies $(\mathrm{x}=0.05)$ favors anisotropic expansion of $\left[\mathrm{NbO}_{6}\right]$ octahedra along the $\mathrm{b}$ axis and then maintain similar equatorial bond lengths $(\mathrm{x}=0.10$ and 0.15 ). For $\mathrm{x}>0.20, \mathrm{Nb}_{2} \mathrm{O}_{5}$ and $\mathrm{TiO}_{2}$ secondary phases were detected by XRD analyses.

Table 1. Unit-cell parameters and volume calculated from the full-pattern profile matching of $\mathrm{NaNb}_{1-\mathrm{x}} \mathrm{Ti}_{\mathrm{x}} \mathrm{O}_{3-0.5 \mathrm{x}}$ XRD patterns $(0 \leq \mathrm{x} \leq 0.15)$. Structures in the $\mathrm{P} 2{ }_{1}$ ma space group were obtained after hydrothermal treatment followed by annealing under air during $6 \mathrm{~h}$ at $600{ }^{\circ} \mathrm{C}$.

\begin{tabular}{lllll} 
& $\mathrm{x}=0$ & $\mathrm{x}=0.05$ & $\mathrm{x}=0.10$ & $\mathrm{x}=0.15$ \\
\hline $\mathrm{a}(\AA)$ & $5.5666(6)$ & $5.5565(5)$ & $5.5520(5)$ & $5.5503(5)$ \\
$\mathrm{b}(\AA)$ & $7.7793(7)$ & $7.7905(5)$ & $7.7902(4)$ & $7.7866(3)$ \\
$\mathrm{c}(\AA)$ & $5.5193(5)$ & $5.5150(4)$ & $5.5124(3)$ & $5.5107(2)$ \\
\hline $\mathrm{V}\left(\AA^{3}\right)$ & $239.01(6)$ & $238.73(5)$ & $238.42(3)$ & $238.16(3)$
\end{tabular}

Environments of $\mathrm{Na}^{+}$and $\mathrm{Nb}^{5+}$ ions in the sodium Tisubstituted niobates were probed using solid state NMR. ${ }^{23} \mathrm{Na}$ $(I=3 / 2)$ and ${ }^{93} \mathrm{Nb}(I=9 / 2)$ NMR spectra are displayed in Figure 3, corresponding to magic angle spinning (MAS) experiments. ${ }^{23} \mathrm{Na}$ MAS NMR spectrum of $\mathrm{NaNbO}_{3}$ must be described as the sum of two distinct signals with complex shape mainly due to second-order quadrupolar interaction. Each component is characterized by an isotropic chemical shift $\left(\delta_{\text {iso }}\right)$, the quadrupolar coupling constant $\left(C_{\mathrm{Q}}\right)$ and the asymmetry parameter $\left(\eta_{\mathrm{Q}}\right)$ of the Electric Field Gradient (EFG). The two observed signals can be clearly associated with the two distinct sites for $\mathrm{Na}$ ions in the $\mathrm{P} 2{ }_{1}$ ma structure. $\mathrm{Na}$ ions located at $\mathrm{Na} 2$ sites give rise to the most intense and sharp signal ( $\delta_{\text {iso }}=-5.3 \mathrm{ppm}, C_{\mathrm{Q}}=1.0 \mathrm{MHz}$ and $\left.\eta_{\mathrm{Q}}=0.8\right)$, whereas the broad signal $\left(\delta_{\text {iso }}=-1.5 \mathrm{ppm}, C_{\mathrm{Q}}=2.1 \mathrm{MHz}\right.$ and $\eta_{\mathrm{Q}}=0.8$ ) corresponds to Na1 local environment. ${ }^{29}$ The latter component allows unambiguous identification of $\mathrm{P} 2{ }_{1} \mathrm{ma}$ versus Pbma, as the signature of $\mathrm{Na} 1$ in the centrosymmetric space group is a sharp signal characterized by $\delta_{\text {iso }}=-0.9 \mathrm{ppm}$, $C_{\mathrm{Q}}=2.2 \mathrm{MHz}$ and $\eta_{\mathrm{Q}}=0.0 .^{23,29}$ Compared to the $\mathrm{NaNbO}_{3}$ polar phase, the Ti-substituted niobates exhibit very similar ${ }^{23} \mathrm{Na}$ NMR spectra except for a global line broadening as the titanium content increases. Thus, the three Ti-substituted com- pounds share similar $\mathrm{Na}$ environments with the polar phase of $\mathrm{NaNbO}_{3}$, in agreement with the $\mathrm{P} 2{ }_{1}$ ma space group deduced from XRD profile matching. The line broadening of both signals is due to slight variations of the $\mathrm{Na}$ environment, leading to a distribution of NMR parameters $\left(\delta_{\text {iso }}, C_{\mathrm{Q}}\right.$ and $\left.\eta_{\mathrm{Q}}\right)$. Such distributions may arise from a structural disorder induced by randomly distributed $\left[\mathrm{Nb}(\mathrm{Ti}) \mathrm{O}_{6}\right]$ octahedra in the vicinity of $\mathrm{Na}$ nuclei in addition to the decrease of $\mathrm{Na}-\mathrm{O}$ bond distances and $\mathrm{Na}$ coordination numbers due to the stabilization of oxygen vacancies. Moreover, the two Na sites become more similar as the Ti content increases. The ${ }^{93} \mathrm{Nb}$ MAS NMR spectra of $\mathrm{NaNb}_{1-\mathrm{x}} \mathrm{Ti}_{\mathrm{x}} \mathrm{O}_{3-0.5 \mathrm{x}}(0 \leq \mathrm{x} \leq 0.15)$ are mainly composed of one broad signal characterized by $-1067 \leq \delta_{\text {iso }} \leq-1060 \mathrm{ppm}$, $C_{\mathrm{Q}} \approx 20 \mathrm{MHz}, \eta_{\mathrm{Q}} \approx 0.6$ and a slight chemical shift anisotropy, as expected for the $\mathrm{NaNbO}_{3} \mathrm{P}_{1}$ ma phase. ${ }^{50,51}$ A minor component due to an unknown $\mathrm{Nb}$-containing impurity was also observed at $\delta_{\text {iso }}=-1005 \mathrm{ppm}$ for compounds with $\mathrm{x} \leq 0.05$. The global intensity of both signals clearly decreases as the $\mathrm{Nb}$ content decreases along with the increasing Ti-doping rate. Furthermore, the isotropic position of the main signal moves towards higher chemical shift values accompanied by a line narrowing. This evolution is consistent with a shortening of average $\mathrm{Nb} / \mathrm{Ti}-\mathrm{O}$ bound, a lowering of $\mathrm{Nb}$ coordination number and the relaxation of octahedron distortion as Ti substitutes for $\mathrm{Nb}$, leading to more symmetrical local environments for $\mathrm{Nb}$.

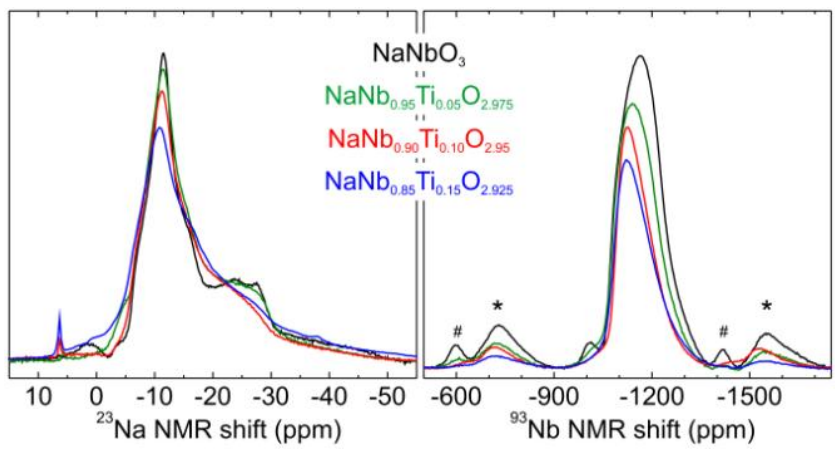

Figure 3. ${ }^{23} \mathrm{Na}$ and ${ }^{93} \mathrm{Nb}(7.05 \mathrm{~T})$ MAS NMR spectra of $\mathrm{NaNb}_{1-\mathrm{x}} \mathrm{Ti}_{\mathrm{x}} \mathrm{O}_{3-0.5 \mathrm{x}}(0 \leq \mathrm{x} \leq 0.15)$ structures in the $\mathrm{P} 2_{1}$ ma space group. * and \#: spinning sidebands (MAS rate: $30 \mathrm{kHz}$ ).

Thus, ${ }^{23} \mathrm{Na} \mathrm{NMR}$ investigations confirm that $\mathrm{NaNb}_{1-\mathrm{x}} \mathrm{Ti}_{\mathrm{x}} \mathrm{O}_{3-0.5 \mathrm{x}}$ $(\mathrm{x}=0.05,0.10$ and 0.15$)$ solid solution adopts the acentric $\mathrm{P} 2{ }_{1}$ ma space group with two $\mathrm{Na}$ similar sites. ${ }^{29}$ Moreover, changes in the ${ }^{93} \mathrm{Nb}$ spectra highlight atomic rearrangements due to $\mathrm{Ti}$ substituting for $\mathrm{Nb}$ in the perovskite-type structure. $\mathrm{Nb} / \mathrm{Ti}-\mathrm{O}$ bonding involving $4 \mathrm{~d} / 3 \mathrm{~d}$ crystal field splitting and covalence is usually associated with the charge transfer transition energy between $\mathrm{O}\left(2 \mathrm{p}^{6}\right)$ valence band and empty $\mathrm{Nb} / \mathrm{Ti}$ $\left(4 d^{0} / 3 d^{0}\right)$ conduction band. Figure 4 shows the diffuse reflectance spectra recorded in the UV-Vis range for the $\mathrm{NaNb}_{1}$. ${ }_{\mathrm{x}} \mathrm{Ti}_{\mathrm{x}} \mathrm{O}_{3-0.5 \mathrm{x}}(0 \leq \mathrm{x} \leq 0.15)$ compounds. A red-shift of the optical band gap was observed for all Ti-doped samples compared to the undoped sodium niobate. In good agreement with the variation of the unit cell parameters, the $\mathrm{Ti}$ substitution for $\mathrm{Nb}$ induces an increase of $4 \mathrm{~d} / 3 \mathrm{~d}$ crystal field splitting and thus a reduction of the optical band gap which tends to an asymptotic value. To the best of our knowledge, this is the first evidence of such polar Ti-substituted sodium niobates with distorted perovskite structures, exhibiting an increase of $4 d / 3 d$ crystal field splitting. 


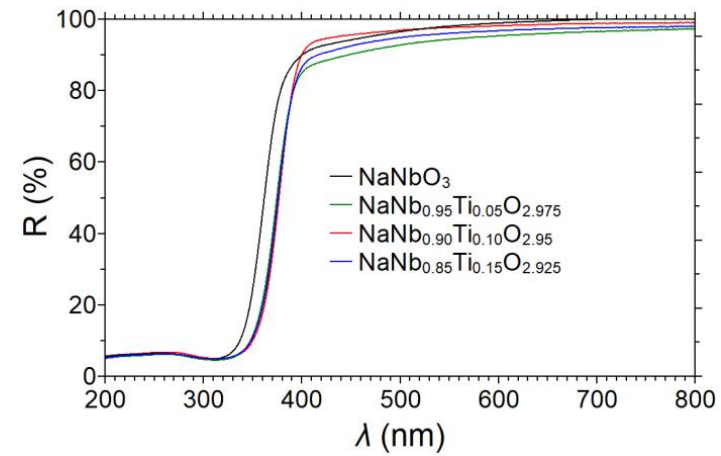

Figure 4. Diffuse reflectance of $\mathrm{NaNb}_{1-\mathrm{x}} \mathrm{Ti}_{\mathrm{x}} \mathrm{O}_{3-0.5 \mathrm{x}}(0 \leq \mathrm{x} \leq$ $0.15)$.

In order to clarify the variation of the transition metal crystal field splitting and especially, the $\mathrm{Nb} / \mathrm{Ti}$ local environments, a detailed analysis of the atomic positions in $\mathrm{NaNb}_{1-\mathrm{x}} \mathrm{Ti}_{\mathrm{x}} \mathrm{O}_{3-0.5 \mathrm{x}}$ structures (crystallizing with $\mathrm{P} 2{ }_{1}$ ma space group) is required. Due to relatively poor crystallinity, the structural study of $600^{\circ} \mathrm{C}$-annealed $\mathrm{NaNb}_{1-\mathrm{x}} \mathrm{Ti}_{\mathrm{x}} \mathrm{O}_{3-0.5 \mathrm{x}}(\mathrm{x}=0.05,0.10,0.15)$ by powder-XRD is limited to space group identification and peak positioning. Higher annealing temperatures are necessary to improve the crystallinity of Ti-doped sodium niobates and then access atomic positions through Rietveld refinements. Previous works on $\mathrm{NaNbO}_{3}$ have evidenced the thermal instability of the $\mathrm{P} 2{ }_{1}$ ma structure. A treatment under air at $950{ }^{\circ} \mathrm{C}$ during $24 \mathrm{~h}$ leads indeed to the formation of a pure $\mathrm{Pbma}$ $\mathrm{NaNbO}_{3}$ polymorph. ${ }^{29}$ In the following section, we discuss the influence of thermal treatment (temperature and time) on the $\mathrm{P} 2{ }_{1}$ ma phase stability for $\mathrm{NaNb}_{0.90} \mathrm{Ti}_{0.10} \mathrm{O}_{2.95}(\mathrm{x}=0.10)$, in comparison to $\mathrm{NaNbO}_{3}$.

Stability of $\mathbf{P 2}{ }_{1}$ ma structure. Annealing under air was carried out at $950{ }^{\circ} \mathrm{C}$ during $24 \mathrm{~h}$. Figure 5 shows the XRD pattern of $\mathrm{NaNb}_{0.90} \mathrm{Ti}_{0.10} \mathrm{O}_{2.95}$ powder. It is compared to $\mathrm{NaNbO}_{3}$ obtained in the exact same conditions and known to crystallize in the Pbma space group. ${ }^{29}$ It corresponds to the most stable polymorph. Surprisingly, the structure of annealed Ti-doped phase can still be described with the $\mathrm{P} 2{ }_{1}$ ma space group, as confirmed by the calculated pattern from Rietveld refinement. The signatures of the $\mathrm{P} 2{ }_{1}$ ma space group are identified in the key range $35.5 \leq 2 \theta \leq 44.5^{\circ}$ with a significant signal around $2 \theta=$ $43.5^{\circ}$ and the absence of inter-reticular planes with odd $\mathrm{k}$ Miller indices of Pbma space group, especially at around 36.8 ${ }^{\circ}$ (Figure $\mathrm{S} 1$ ). Ti substitution for $\mathrm{Nb}$ thus stabilizes the structure in the $\mathrm{P} 2{ }_{1}$ ma space group. Three main effects of substituting $\mathrm{Ti}$ for $\mathrm{Nb}$ can be highlighted: the lower ionic size and $\mathrm{d}$ orbital reduction of $\mathrm{Ti}^{4+}$, the expected comparable secondorder Jahn-Teller effect of $\mathrm{Nb}^{5+}$ and $\mathrm{Ti}^{4+}$ ions and the creation of oxygen vacancies. This less symmetrical $\mathrm{NaNb}_{0.90} \mathrm{Ti}_{0.10} \mathrm{O}_{2.95}$ structure is obtained from a mixture of Pbma and P $2{ }_{1}$ ma structures, even after a high-temperature-long-time thermal treatment $\left(950{ }^{\circ} \mathrm{C}, 24 \mathrm{~h}\right)$. We investigated also the structural features of $\mathrm{NaNb}_{0.80} \mathrm{Ti}_{0.20} \mathrm{O}_{2.90}$ complex oxide containing larger Ti content $(\mathrm{x}=0.20)$ and obtained in similar conditions. Figure $\mathrm{S} 2$ shows that the structure is fully described in the $\mathrm{P} 2{ }_{1} \mathrm{ma}$ space group by XRD, suggesting that the switch from Pbma space group for $\mathrm{NaNbO}_{3}$ to $\mathrm{P} 2_{1}$ ma for $\mathrm{NaNb}_{1-\mathrm{x}} \mathrm{Ti}_{\mathrm{x}} \mathrm{O}_{3-0.5 \mathrm{x}}$ is a general behavior, up to $\mathrm{x}=0.20$. Local environments of niobi$\mathrm{um} /$ titanium and sodium in the $\mathrm{NaNb}_{0.90} \mathrm{Ti}_{0.10} \mathrm{O}_{2.95}$ phase are compared to niobium and sodium in $\mathrm{NaNbO}_{3}$ (polar phase obtained after heat treatment at $600{ }^{\circ} \mathrm{C}$ during $6 \mathrm{~h}$ ) in term of (i) geometry through site symmetries and distortions and (ii) stability using Madelung potential calculations.
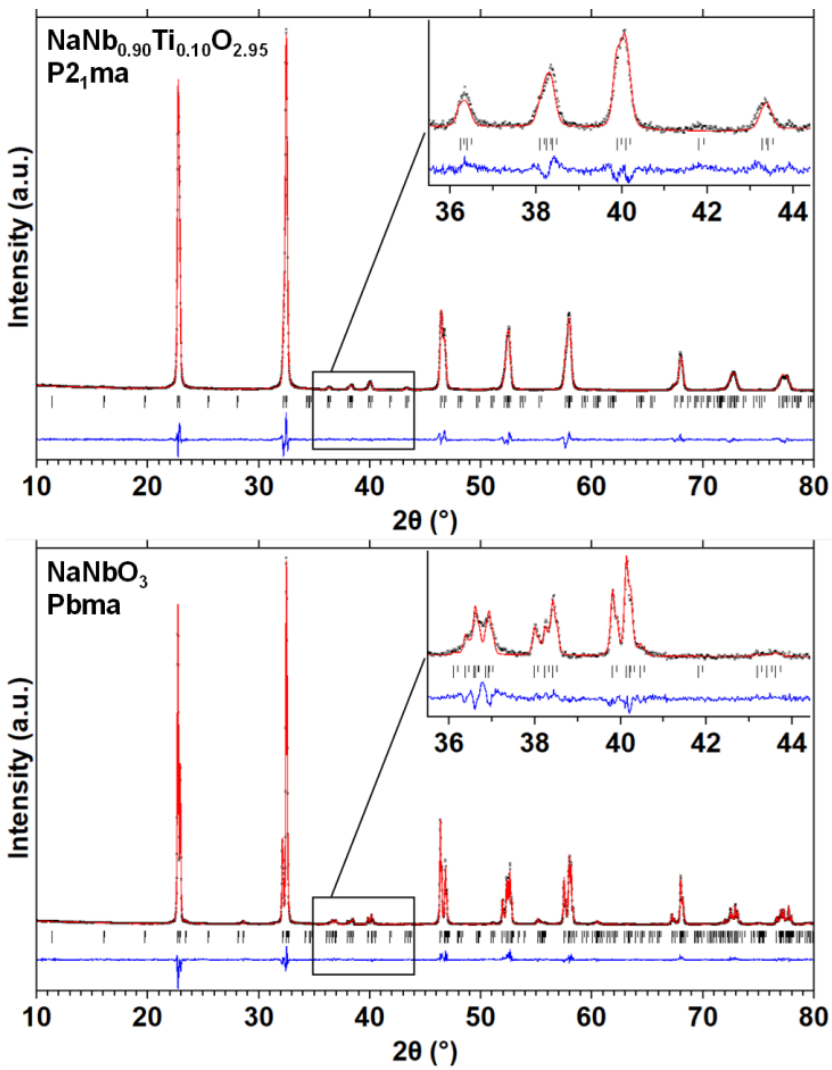

Figure 5. Powder-XRD experimental data (black crosses) and calculated patterns (red line) from Rietveld structural refinements of $\mathrm{NaNbO}_{3}$ and $\mathrm{NaNb}_{0.90} \mathrm{Ti}_{0.10} \mathrm{O}_{2.95}$ after annealing under air at $950{ }^{\circ} \mathrm{C}$ during $24 \mathrm{~h}$. Blue lines represent the difference between experiment and calculation. ${ }^{\mathrm{a}} \mathrm{NaNbO}_{3}$ in the Pbma space group from ref. 29.

Geometric and energetic features of atomic environments in the $\mathrm{NaNb}_{0.90} \mathrm{Ti}_{0.10} \mathrm{O}_{2.95}$ complex oxide are first investigated from the structure refined using powder XRD data. Atomic positions, fixed isotropic thermal displacement parameters and reliability factors are listed in Table 2 . Due the low amount of oxygen vacancies in this compound, it was impossible to clearly identify the oxygen sites that are partially occupied. Local environments of metal elements $\mathrm{Nb} / \mathrm{Ti}$ and $\mathrm{Na}$ in $\mathrm{NaNb}_{0.90} \mathrm{Ti}_{0.10} \mathrm{O}_{2.95}$ are represented in Figure 6. They are compared to the equivalent sites in $\mathrm{NaNbO}_{3}\left(\mathrm{P} 2_{1}\right.$ ma space group). ${ }^{29}$ Bond lengths in $\left[\mathrm{NbO}_{6}\right]$ and $\left[\mathrm{Nb}(\mathrm{Ti}) \mathrm{O}_{6}\right]$ are also reported (Table 3 ). In the equatorial plane, the bond distances $\mathrm{d}(\mathrm{Nb} / \mathrm{Ti}-\mathrm{O} 3)$ and $\mathrm{d}(\mathrm{Nb} / \mathrm{Ti}-\mathrm{O} 4)$ are reduced and closer one to each other in the Ti substituted structure, as predicted by the decrease of a and c parameters. However, the $\left[\mathrm{Nb}(\mathrm{Ti}) \mathrm{O}_{6}\right]$ octahedron is much more distorted in the equatorial plane with four different bond lengths $(2.09,2.04,1.92$ and $1.88 \AA)$ than in sodium niobate with $\mathrm{P} 2{ }_{1}$ ma structure where $2+2$ bond distances are identified (2.09 and $1.88 \AA$ ). Concerning the apical bond distances along the $\mathrm{b}$ direction, the two bond lengths are almost equal (2.01 and $2.02 \AA)$ for the Tisubstituted niobate, while they are radically different in sodium niobate with $\mathrm{P} 2{ }_{1}$ ma network ( 2.05 and $1.97 \AA$ ). The reduction of distortion along the apical axis contribute to enlarge the distortion in the equatorial plane. In all structures, sodium atoms are equally distributed between two distinct sites. Both 
sites are represented in Figure 6 for $\mathrm{NaNbO}_{3}$ and $\mathrm{NaNb}_{0.90} \mathrm{Ti}_{0.10} \mathrm{O}_{2.95}$, with their twelve surrounding oxygen atoms: four $\mathrm{O} 1$, four $\mathrm{O} 3$ and four $\mathrm{O} 4$ for $\mathrm{Na} 1$ and four $\mathrm{O} 2$, four $\mathrm{O} 3$ and four $\mathrm{O} 4$ for Na2. Sodium-to-oxygen distances are also reported on Table S1. Both environments are identically characterized by a lower symmetry than the perfect icosahedral symmetry for a 12-fold coordination. Sodium-to-oxygen distances between 2.2 and $3.4 \AA$ strongly deviate from the average value of ca. $2.8 \AA$. In addition, only a planar symmetry is observed, with five atoms in the plane mirror: $\mathrm{Na} 1 / \mathrm{Na} 2$ atom and the four $\mathrm{O} 1 / \mathrm{O} 2$ atoms. Na1-O1 and $\mathrm{Na} 2-$ $\mathrm{O} 2$ distances change significantly from a structure to the other. In $\mathrm{NaNbO}_{3}, \mathrm{Na} 1$ is environed by 2 close $\mathrm{O} 1$ atoms $(2.53$ and $2.55 \AA$ ) in cis position and two distant ones (3.01 and $3.03 \AA$ ). This $2+2$ planar geometry switches to a more distorted one for $\mathrm{NaNb}_{0.90} \mathrm{Ti}_{0.10} \mathrm{O}_{2.95}$ with four distinct distances $(2.20,2.45,3.19$ and $3.40 \AA$ ). The same trend is observed for $\mathrm{Na} 2$ surrounded by $\mathrm{O} 2$ atoms, with a smaller but still significant increase of the difference between the two short Na2-O2 or the two long Na2$\mathrm{O} 2$ bond distances, when $\mathrm{Ti}$ substitutes for $\mathrm{Nb}$. On the contrary, $\mathrm{Na}-\mathrm{O} 3$ and $\mathrm{Na}-\mathrm{O} 4$ bond distances are weakly influenced by the Ti substitution for $\mathrm{Nb}$.

Table 2. Refined atomic positions, atomic displacement parameters and refinement parameters of $\mathrm{NaNb}_{0.90} \mathrm{Ti}_{0.10} \mathrm{O}_{2.95}$ in the $\mathrm{P} 2{ }_{1}$ ma space group.

\begin{tabular}{|c|c|c|}
\hline atom & & coordinate \\
\hline $\mathrm{Nb} / \mathrm{Ti}$ & $x$ & $0.2603(3)$ \\
\hline \multirow[t]{2}{*}{$(0.90 / 0.10)$} & $y$ & $0.2495(10)$ \\
\hline & z & $0.2474(7)$ \\
\hline \multirow[t]{3}{*}{$\mathrm{Na} 1$} & $x$ & $0.293(3)$ \\
\hline & $y$ & 0 \\
\hline & z & $0.746(3)$ \\
\hline \multirow[t]{3}{*}{$\mathrm{Na} 2$} & $\mathrm{x}$ & $0.292(3)$ \\
\hline & $y$ & 0.5 \\
\hline & $\mathrm{z}$ & $0.744(3)$ \\
\hline \multirow[t]{3}{*}{01} & $\mathrm{x}$ & $0.184(4)$ \\
\hline & $y$ & 0 \\
\hline & z & $0.315(4)$ \\
\hline \multirow[t]{3}{*}{$\mathrm{O} 2$} & $\mathrm{x}$ & $0.228(4)$ \\
\hline & $y$ & 0.5 \\
\hline & $z$ & $0.165(5)$ \\
\hline \multirow[t]{3}{*}{$\mathrm{O} 3$} & $\mathrm{x}$ & $0.044(3)$ \\
\hline & $y$ & $0.267(3)$ \\
\hline & z & $0.556(4)$ \\
\hline \multirow[t]{2}{*}{$\mathrm{O} 4$} & $x$ & $-0.020(4)$ \\
\hline & $\begin{array}{l}y \\
z\end{array}$ & $\begin{array}{l}0.228(3) \\
0.010(4)\end{array}$ \\
\hline$\beta_{\text {iso }}(\mathrm{Nb})\left(\AA^{2}\right)$ & & 0.5 \\
\hline$\beta_{\text {iso }}(\mathrm{Na})\left(\AA^{2}\right)$ & & 1 \\
\hline$\beta_{\text {iso }}(\mathrm{O})\left(\AA^{2}\right)$ & & 1 \\
\hline $\mathrm{R}_{\mathrm{p}}(\%)$ & & 4.24 \\
\hline$w R_{p}(\%)$ & & 5.98 \\
\hline $\mathrm{R}_{\mathrm{all}}(\%)$ & & 4.18 \\
\hline$w R_{\text {all }}(\%)$ & & 5.42 \\
\hline
\end{tabular}

Finally, taking into account the competitive bonds sequence $\mathrm{Na1}(2)-\mathrm{O} 1(2)-\mathrm{Nb}-\mathrm{O} 3(4)$, the strong variation of Na1-O1 and $\mathrm{Na} 2-\mathrm{O} 2$ bond lengths after $\mathrm{Ti}$ substitution for $\mathrm{Nb}$ leads to the reduction of $\mathrm{Nb}-\mathrm{O} 1 / \mathrm{O} 2$ apical distortion and consequently to the exaltation of the distortion in the equatorial plane. The combined effects of the lower ionic size should explain the global variation of $\left[\mathrm{Nb}(\mathrm{Ti}) \mathrm{O}_{6}\right]$ octahedral distortion in this series: the increase of crystal field splitting as well as the creation of oxygen vacancies associated to $\mathrm{Ti}^{4+}$ substitution for $\mathrm{Nb}^{5+}$. An average increase of the $\mathrm{d}$ crystal field splitting (see optical band gap evolution in Figure 4) is observed and a stronger distortion in the $\left[\mathrm{Nb}(\mathrm{Ti}) \mathrm{O}_{4}\right]$ equatorial plane is identified as the apical $\mathrm{Nb}(\mathrm{Ti})-\mathrm{O}$ distances become similar.
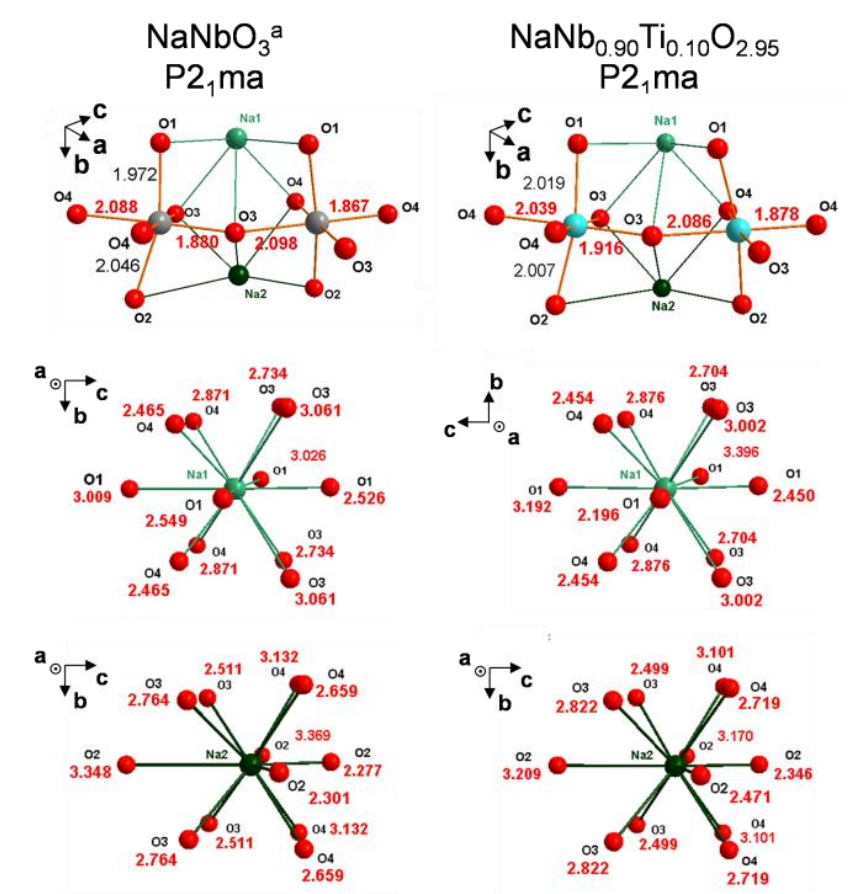

Figure 6. $\mathrm{Nb}$ or $\mathrm{Nb} / \mathrm{Ti}, \mathrm{Na} 1$ and $\mathrm{Na} 2$ local environments in $\mathrm{NaNbO}_{3}$ and $\mathrm{NaNb}_{0.90} \mathrm{Ti}_{0.10} \mathrm{O}_{2.95}{ }^{\mathrm{a}} \mathrm{NaNbO}_{3}$ in the $\mathrm{P} 2{ }_{1}$ ma space group from ref. 29. Bond lengths are expressed in ångström unit.

Table 3. Distortion of $\left[\mathrm{NbO}_{6}\right]$ and $\left[\mathrm{Nb}(\mathrm{Ti}) \mathrm{O}_{6}\right]$ in $\mathrm{NaNbO}_{3}$ and $\mathrm{NaNb}_{0.90} \mathrm{Ti}_{0.10} \mathrm{O}_{2.95}$, respectively. ${ }^{\mathrm{a}} \mathrm{NaNbO}_{3}$ in the $\mathrm{P}{ }_{1}$ ma space group from ref.29. (avg: average lengths, $\Delta$ : deviation to average length)

\begin{tabular}{ccccc} 
& \multicolumn{2}{c}{$\mathrm{NaNbO}_{3} \mathrm{a}^{\mathrm{a}}$} & \multicolumn{2}{c}{$\mathrm{NaNb}_{0.9} \mathrm{Ti}_{0.1} \mathrm{O}_{2.95}$} \\
\multicolumn{2}{c}{$\mathrm{d}(\mathrm{Nb}-\mathrm{O})(\AA)$} & $\Delta$ to avg (\%) & $\mathrm{d}\left(\mathrm{Nb} / \mathrm{Ti}-\mathrm{O}_{\mathrm{i}}\right)(\AA)$ & $\Delta$ to avg $(\%)$ \\
\hline $\mathrm{avg}$ & 1.992 & $\mathrm{X}$ & 1.991 & $\mathrm{X}$ \\
$\mathrm{O} 1$ & $1.972(5)$ & -1.0 & $2.019(9)$ & +1.4 \\
$\mathrm{O} 2$ & $2.046(7)$ & +2.7 & $2.007(1)$ & +0.8 \\
$\mathrm{O} 3$ & $1.880(2)$ & -5.6 & $1.916(2)$ & -3.8 \\
$\mathrm{O} 3$ & $2.098(2)$ & +5.4 & $2.086(2)$ & +4.8 \\
O4 & $1.867(2)$ & -6.2 & $1.878(2)$ & -5.7 \\
O4 & $2.088(2)$ & +4.8 & $2.039(2)$ & +2.4
\end{tabular}

The relative stability of atom sites was evaluated in $\mathrm{NaNbO}_{3}$ and $\mathrm{NaNb}_{0.90} \mathrm{Ti}_{0.10} \mathrm{O}_{2.95}$ (both in $\mathrm{P} 2{ }_{1}$ ma space group) by calculating their Madelung potential through Ewald's method, an ionic model taking into account the punctual charge at atom positions of the framework. ${ }^{52}$ Potentials are displayed in Table 4. The potential of $\mathrm{Nb}$ site is not affected by $\mathrm{Ti}$ substitution for $\mathrm{Nb}$, in agreement with the average $\mathrm{Nb}-\mathrm{O}$ bond lengths evolution in the distorted $\left[\mathrm{Nb}(\mathrm{Ti}) \mathrm{O}_{6}\right]$ octahedron. $\mathrm{Na} 1$ site is less stable than $\mathrm{Na} 2$ site in $\mathrm{NaNbO}_{3}$ according to the lower absolute value of the Madelung potential. In comparison, the order of stability of $\mathrm{Na}$ sites is inverted in $\mathrm{NaNb}_{0.90} \mathrm{Ti}_{0.10} \mathrm{O}_{2.95}$. This trend follows the evolution of the two shortest Na1-O1 or $\mathrm{Na} 2-\mathrm{O} 2$ bond distances, with the expected observation that closer oxygen atoms leads to better coulombic interactions. For both structures, the difference in potentials remains limited to ca. $1 \mathrm{~V}$ between $\mathrm{Na} 1$ and $\mathrm{Na} 2$ sites, which are thus of almost similar stability. Moreover, as mentioned previously, taking into account competitive bonds in the $\mathrm{Na} 1(2)-\mathrm{O} 1(2)-\mathrm{Nb}$ sequence, a stabilization (destabilization) of $\mathrm{Na} 1(\mathrm{Na} 2)$ sites in 
Ti-substituted sodium niobates leads to a destabilization (stabilization) of $\mathrm{O} 1(\mathrm{O} 2)$ atomic positions. Then, the Madelung potentials of the four $\mathrm{O}$ sites are very similar in agreement with the evolution of $\mathrm{Nb}-\mathrm{O}$ bond lengths. Ti substitution for $\mathrm{Nb}$ affects the $\mathrm{Na}$ local sphere through the occurrence of oxygen vacancies and the influence of the steric effect as the Goldschmidt factor tends to 1 . $\mathrm{Na} 1$ and $\mathrm{Na} 2$ atomic position are correlated to $\mathrm{O} 1$ and $\mathrm{O} 2$ apical oxygen sites and contribute to the distortion along the $\mathrm{b}$ axis. Then, the lower the distortion in the apical direction, the higher the distortion in the equatorial plane. Finally, the second-order Jahn-Teller effect $(\mathrm{Nb} / \mathrm{Ti})$ is enhanced in sodium niobates after $\mathrm{Ti}$ substitution for $\mathrm{Nb}$.

Table 4: Madelung Potentials of atomic sites in $\mathrm{NaNbO}_{3}$ and $\mathrm{NaNb}_{0.90} \mathrm{Ti}_{0.10} \mathrm{O}_{2.95}$. ${ }^{\mathrm{a}} \mathrm{NaNbO}_{3}$ in the $\mathrm{P} 2{ }_{1}$ ma space group from ref. 29.

\begin{tabular}{rcc} 
& \multicolumn{2}{c}{ Madelung potentials } \\
atomic & $\mathrm{NaNbO}_{3}{ }^{a}$ & $\mathrm{NaNb}_{0.9} \mathrm{Ti}_{0.1} \mathrm{O}_{2.95}$ \\
site & $\mathrm{P} 2_{1} \mathrm{ma}^{2}$ & $-52.1 \mathrm{~V}$ \\
$\mathrm{Nb}, \mathrm{Nb} / \mathrm{Ti}$ & $-52.1 \mathrm{~V}$ & $-13.9 \mathrm{~V}$ \\
$\mathrm{Na} 1$ & $-12.8 \mathrm{~V}$ & $-12.8 \mathrm{~V}$ \\
$\mathrm{Na} 2$ & $-13.8 \mathrm{~V}$ & $+24.4 \mathrm{~V}$ \\
$\mathrm{O} 1$ & $+25.7 \mathrm{~V}$ & $+24.8 \mathrm{~V}$ \\
$\mathrm{O} 2$ & $+23.6 \mathrm{~V}$ & $+25.3 \mathrm{~V}$ \\
$\mathrm{O} 3$ & $+26.2 \mathrm{~V}$ & $+25.3 \mathrm{~V}$
\end{tabular}

The $\mathrm{P} 2{ }_{1} \mathrm{ma}$ polymorphs of $\mathrm{NaNb}_{0.90} \mathrm{Ti}_{0.10} \mathrm{O}_{2.95}$ and $\mathrm{NaNb}_{0.80} \mathrm{Ti}_{0.20} \mathrm{O}_{2.90}$ were shown to be specifically obtained even after an annealing treatment at $950{ }^{\circ} \mathrm{C}$ under air, suggesting that this structure is the most stable at room temperature. Structural differences with the isomorph $\mathrm{NaNbO}_{3}$ explain this original result: the most important differences are observed for $\mathrm{O} 1$ and $\mathrm{O} 2$ sites, favoring two similar $\mathrm{Na} 1$ and $\mathrm{Na} 2$ sites with distorted environments. These structural features are well adapted to the $\mathrm{P} 2{ }_{1}$ ma space group with sodium sites sharing the same site symmetry in contrast with the Pbma structure.

In absence of heat treatment, the formation of a polymorphic mixture (Figure 1) is attributed to inhomogeneity of titanium distribution and poor crystallinity. In the hydrothermal process adapted from Handoko et al., ${ }^{48} \mathrm{Nb}_{2} \mathrm{O}_{5}$ is known to react with caustic soda $(6 \mathrm{M})$ to form $\mathrm{NaNbO}_{3}$ through a dissolutionreprecipitation mechanism. The titanium precursor stabilized in acidic solution precipitates as soon as it is in contact with the basic reactive medium. The mechanism during the hydrothermal step remains unclear, but one can expect a similar dissolution-reprecipitation of niobium and titanium species more or less together. Heterogeneity of titanium dispersion in the post-hydrothermal material is thus suggested, with structural domains in the Pbma space group occurring when the titanium content is locally too low to enable the $\mathrm{P} 2{ }_{1}$ ma transition. Heat treatments favor elemental homogeneity, triggering phase transition. Higher annealing temperature of $950{ }^{\circ} \mathrm{C}$ (Figures 5 and S2) proved to efficiently annihilate local disorder observed by XRD and ${ }^{23} \mathrm{Na}$ NMR after heating at $600{ }^{\circ} \mathrm{C}$ (Figures 2 and 3 ).

Interestingly, unit-cell parameters evolutions described on $\mathrm{P} 2{ }_{1}$ ma polymorphs obtained at $600{ }^{\circ} \mathrm{C}$ (Table 1 ) already suggested that $\mathrm{O} 1$ and $\mathrm{O} 2$ undergo the most important rearrangements by substituting Ti for $\mathrm{Nb}$. Indeed $\mathrm{Nb} / \mathrm{Ti}-\mathrm{O} 1$ and $\mathrm{Nb} / \mathrm{Ti}$ $\mathrm{O} 2$ are oriented along the $\mathrm{b}$ axis and $\mathrm{b}$ cell parameter is elongated after Ti-substitution. Oxygen organization is characterized by the increase in the length of $\mathrm{Nb} / \mathrm{Ti}-\mathrm{O}$ shortest bonds.
Such elongations weaken the charge transfers from oxygen $\left(2 p^{6}\right)$ valence band to transition metal $d$ vacant orbitals, in good agreement with the decrease of the optical band gap for Ti-substituted sodium niobates (Figure 4). Supposing that charge transfers of the shortest $\mathrm{Nb} / \mathrm{Ti}$ bonds govern the absorption properties, the increase in the wavelength of absorption edge (Figure 4), i.e. the decrease in the band gap energy is directly attributed to the increase in the shortest bond lengths. The absorption front is independent on $\mathrm{Ti}$ content from $\mathrm{x}=$ 0.05 , suggesting that shortest bonds do not evolve much for $\mathrm{x}$ $\geq 0.05$. Moreover, as mentioned above, the crystal field splitting associated to the second-order Jahn-Teller distortion increases after Ti-substitution. The two apical Nb/Ti-O distances remain close to about $2.01 \AA$, which is similar to theoretical $\mathrm{Nb}-\mathrm{O}$ and $\mathrm{Ti}-\mathrm{O}$ distances deduced from ionic radii (2.04 and $2.01 \AA$, respectively). ${ }^{26}$ In the meantime, four different $\mathrm{Nb}(\mathrm{Ti})-\mathrm{O}$ bond lengths $(2.09,2.04,1.92$ and $1.88 \AA$ ) have been deduced from powder XRD-Rietveld analysis, while only a $2+2$ distortion $(2.09$ and $1.88 \AA$ ) is observed in the equatorial plane of sodium niobate crystallizing with the $\mathrm{P} 2{ }_{1}$ ma structure. For Ti-substituted sodium niobate, such a distortion in the equatorial plane must thus explain the increase of the crystal field splitting. Moreover, the occurrence of a low rate of oxygen vacancies leads also to stabilize a small content of 5-fold coordinated $\mathrm{Nb}^{5+} / \mathrm{Ti}^{4+}$ sites assisted by the second-order JahnTeller effect which contribute to enhance the $4 d / 3 d$ crystal field splitting and reduce the optical band gap.

Madelung potentials calculations showed the convergence in stability of the four distinct oxygen sites. The three major consequences of $\mathrm{Ti}$ substitution are (i) the stabilizing factor of the $\mathrm{P} 2{ }_{1}$ ma polymorph versus $\mathrm{Pbma}$, (ii) the convergence in term of local environment of $\mathrm{O} 1$ and $\mathrm{O} 2$ on one side, of $\mathrm{O} 3$ and $\mathrm{O} 4$ on the other and (iii) $\mathrm{O}$ vacancies with controlled concentration. The three effects are ought to impact oxygen mobility. Ionic conductivity of $\mathrm{NaNb}_{1-\mathrm{x}} \mathrm{Ti}_{\mathrm{x}} \mathrm{O}_{3-0.5 \mathrm{x}}$ is explored hereafter for temperatures ranging from 300 to $700{ }^{\circ} \mathrm{C}$. $\mathrm{NaNbO}_{3}$ is known to undergo six phase transitions with temperature, five of them being in this range of temperature. $^{21,24,25,30}$ To the best of our knowledge, the thermal phase transitions in $\mathrm{NaNb}_{1-\mathrm{x}} \mathrm{Ti}_{\mathrm{x}} \mathrm{O}_{3-0.5 \mathrm{x}}$ family $(0.05 \leq \mathrm{x} \leq 0.15)$ have never been reported. They are presented in the next section before ionic conduction properties are examined.

Polymorphism with temperature. XRD of $\mathrm{NaNb}_{1-\mathrm{x}} \mathrm{Ti}_{\mathrm{x}} \mathrm{O}_{3-0.5 \mathrm{x}}$ $(\mathrm{x}=0.05,0.10,0.15)$ was performed at different temperatures between room temperature (RT) and $700{ }^{\circ} \mathrm{C}$. Figure 7 displays selected key regions of XRD diagrams for $\mathrm{NaNb}_{0.90} \mathrm{Ti}_{0.10} \mathrm{O}_{2.95}$. Bragg peak positions were obtained from full-pattern profile matchings. Note that the $2 \theta$ interval $\left[41-53^{\circ}\right]$ with a Co $\mathrm{K} \alpha_{1} / \mathrm{K}_{2}$ anti-cathode (Figure 7a) corresponds to the region [35.5-44.5 $5^{\circ}$ with a $\mathrm{Cu} \mathrm{K \alpha} \alpha_{1} / \mathrm{K}_{2}$ anti-cathode (Figure 5, inset). Two phase transitions are observed: (i) $\mathrm{P} 2{ }_{1}$ ma (orthorhombic system) $\leftrightarrow \mathrm{Cmcm}$ (orthorhombic system) between 200 and $300{ }^{\circ} \mathrm{C}$ and (ii) $\mathrm{Cmcm}$ (orthorhombic system) $\leftrightarrow \mathrm{Pm}-3 \mathrm{~m}$ (cubic system) between 500 and $600{ }^{\circ} \mathrm{C}$. For the ideal cubic structure, the cell is fully described with a unique parameter $\mathrm{a}_{\text {cubic }} \approx$ $3.9 \AA$. Transition to the orthorhombic $\mathrm{Cmcm}$ space group is accompanied by the doubling of each unit-cell parameter. In the Glazer notations ${ }^{21,22}$, the P21ma and $\mathrm{Cmcm}$ models have different octahedral tilting and orientations $\left(\mathrm{a}^{-} \mathrm{b}^{+} \mathrm{a}^{-}\right.$and $\mathrm{a}^{0} \mathrm{~b}^{+} \mathrm{c}$ respectively). A comparison of profile maching (data at $\mathrm{T}=100^{\circ} \mathrm{C}$ ) or Rietveld analysis $\left(\right.$ data at $\mathrm{T}=300^{\circ} \mathrm{C}$ ) with reliability factors, represented in Figure $\mathrm{S} 5$ and $\mathrm{S} 6$ respectively $\left(\mathrm{NaNb}_{0.9} \mathrm{Ti}_{0.10} \mathrm{O}_{2.95}\right.$ composition) and taking into account the 
two space groups $\mathrm{P} 21 \mathrm{ma}$ and $\mathrm{Cmcm}$, allow determining the best structural hypothesis despite these two space groups are very difficult to distinguish from powder XRD. The phase transition results in the occurrence of several reflections lines which did not exist with the cubic structures (Figure 7a) and the splitting of most already existing peaks (Figure 7b). RT structure is described in the $\mathrm{P} 2{ }_{1}$ ma space group with a $\times b \times c=\sqrt{ } 2 a_{\text {cubic }} \times 2 a_{\text {cubic }} \times \sqrt{ } 2 a_{\text {cubic }}$. The transition between 200 to $300{ }^{\circ} \mathrm{C}$ is observed thanks to the splitting of most XRD lines in Figure $7 \mathrm{a}$.

Finally, profile matching of $\mathrm{NaNb}_{0.9} \mathrm{Ti}_{0.10} \mathrm{O}_{2.95}$ XRD patterns recorded at $\mathrm{T}=100^{\circ} \mathrm{C}(\mathrm{P} 21 \mathrm{ma}), 300^{\circ} \mathrm{C}(\mathrm{Cmcm})$ and $700^{\circ} \mathrm{C}$ $(\mathrm{Pm}-3 \mathrm{~m})$, represented on figure $7 \mathrm{~b}$, illustrate the slight differences between the three space groups.

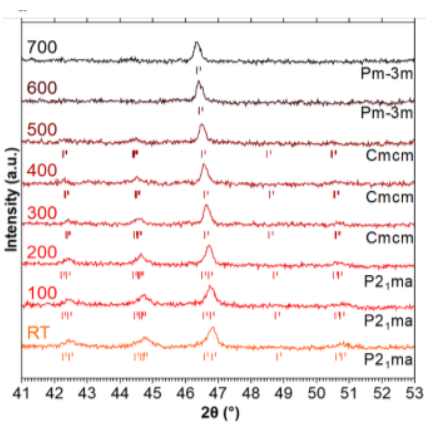

Figure 7a. $\mathrm{XRD}$ patterns of $\mathrm{NaNb}_{0.90} \mathrm{Ti}_{0.10} \mathrm{O}_{2.95}$ for a) $41^{\circ} \leq 2 \theta \leq 53^{\circ}$ and b) $53^{\circ} \leq 2 \theta \leq 56^{\circ}$ versus temperature. RT: room temperature, other temperatures in ${ }^{\circ} \mathrm{C}$. Note the different XRD Co $\mathrm{K} \alpha_{1} / \mathrm{K} \alpha_{2}$ source used here $(\lambda=1.7890$ and $1.7919 \AA$, respectively). Reflection positions were calculated from full-pattern profile matching.

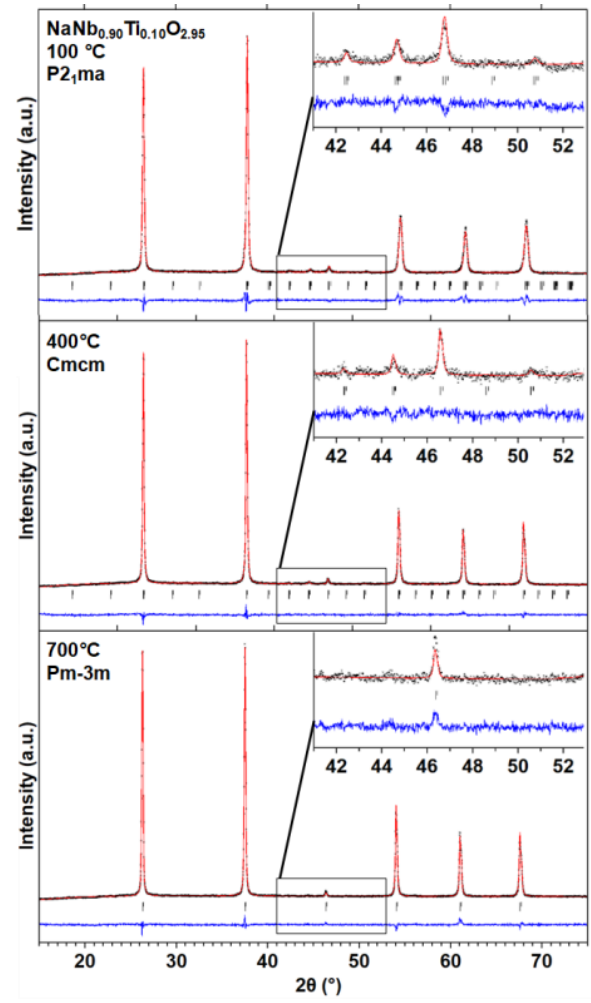

Figure 7b: Thermal polymorphism of $\mathrm{NaNb}_{0.90} \mathrm{Ti}_{0.10} \mathrm{O}_{2.95}$. $\mathrm{XRD}$ patterns were acquired at $100^{\circ} \mathrm{C}, 300^{\circ} \mathrm{C}$ and $700^{\circ} \mathrm{C}$ with a Co $\mathrm{K} \alpha 1 / \mathrm{K} \alpha 2$ source $(\lambda=1.7890$ and $1.7919 \AA$, respectively) under helium. Profile matchings confirm structures in P21ma $\left(\mathrm{T}=100^{\circ} \mathrm{C}\right), \quad \mathrm{Cmcm}\left(\mathrm{T}=300^{\circ} \mathrm{C}\right)$ and $\mathrm{Pm}-3 \mathrm{~m}\left(\mathrm{~T}=700^{\circ} \mathrm{C}\right)$ space groups.

For every temperature, the reduced parameter cell $\mathrm{a}_{\text {cubic }}$ was calculated for the structure deduced from full pattern profile matching of the XRD diagram. Figure 8 shows the thermal evolution of $\mathrm{a}_{\text {cubic }}$ for $\mathrm{NaNb}_{1-\mathrm{x}} \mathrm{Ti}_{\mathrm{x}} \mathrm{O}_{3-0.5 \mathrm{x}}(\mathrm{x}=0.05,0.10,0.15)$. For the three compositions, the correlation deviates clearly from the linear thermal expansion between 200 and $300{ }^{\circ} \mathrm{C}$ due to the low temperature (low-T) phase transition P $2{ }_{1}$ ma $\leftrightarrow$ $\mathrm{Cmcm}$. The cubic phase transition also occurs in all cases, although the non-linear thermal expansion is not as obvious as at low-T. Additional XRD data (Figures S3 and S4) evidence the structural transition from the space group P21 ma to $\mathrm{Cmcm}$ and finally Pm-3m for $\mathrm{x}=0.05$ and 0.15 . Pairs of octahedra and $\mathrm{Nb} / \mathrm{Ti}-\mathrm{O}$ distances shown on Figure 8 are deduced from Rietveld refinements of $\mathrm{NaNb}_{0.90} \mathrm{Ti}_{0.10} \mathrm{O}_{2.95}$ XRD patterns at RT (see also Table 3), 400 and $700{ }^{\circ} \mathrm{C}$ (Figure S4). The polymorph (Cmcm space group) at intermediate temperature (mid$\mathrm{T}$ ) is closer to the perfect cubic perovskite structure (high-T polymorph) with (i) an almost perfect octahedron $\left[\mathrm{Nb}(\mathrm{Ti}) \mathrm{O}_{6}\right]$ compared to the distorted one in the low-T polymorph $\left(\mathrm{P} 2{ }_{1} \mathrm{ma}\right.$ space group) and (ii) identical $\mathrm{x}=0$ and $\mathrm{z}=1 / 4$ coordinates for $\mathrm{Na} 1$ and $\mathrm{Na} 2$ sites fixed by the symmetry of the $\mathrm{Cmcm}$ space group, $(0, \mathrm{y}, 1 / 4)$ for both sites, turning into a single $\mathrm{Na}$ site in the high-T polymorph. The most important rearrangements thus occur for $\mathrm{P} 2{ }_{1}$ ma $\leftrightarrow \mathrm{Cmcm}$. Accordingly, the strongest deviation to linear thermal expansion occurs between this polymorphic transition, between 200 and $300{ }^{\circ} \mathrm{C}$. Na site is still a key structural characteristic which contributes to the $\mathrm{Nb} / \mathrm{Ti}$ second order Jahn-Teller distortion.

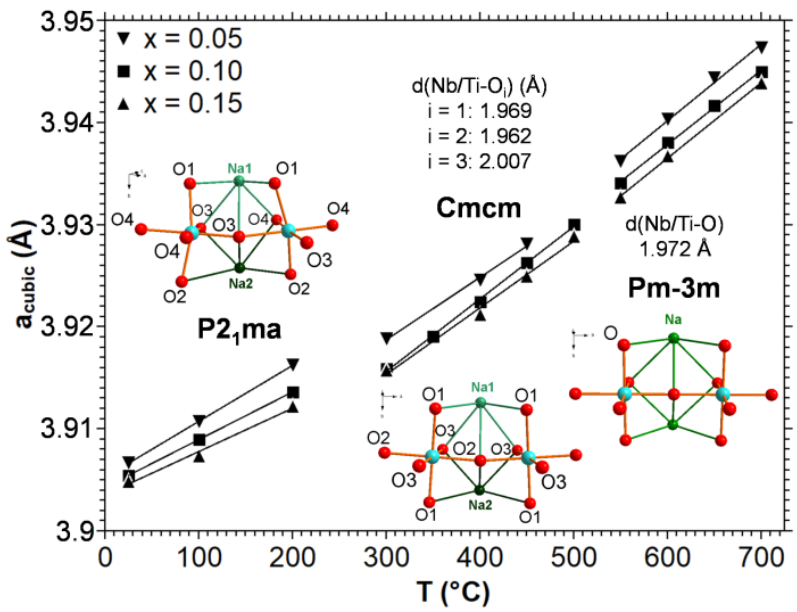

Figure 8. Non-linear thermal expansion induced by phase transitions. Thermal evolutions of reduced cell parameter for $\mathrm{NaNb}_{1-\mathrm{x}} \mathrm{Ti}_{\mathrm{x}} \mathrm{O}_{3-0.5 \mathrm{x}}(\mathrm{x}=0.05,0.10,0.15)$. Pairs of $\left[\mathrm{Nb}(\mathrm{Ti}) \mathrm{O}_{6}\right]$ octahedra are represented in $\mathrm{NaNb}_{0.90} \mathrm{Ti}_{0.10} \mathrm{O}_{2.95}$ at $\mathrm{RT}\left(\mathrm{P} 2_{1} \mathrm{ma}\right.$ space group), $400{ }^{\circ} \mathrm{C}(\mathrm{Cmcm})$ and $700{ }^{\circ} \mathrm{C}(\mathrm{Pm}-3 \mathrm{~m})$.

Two thermal phase transitions were revealed for Ti-substituted sodium niobates. They are both accompanied by an increase in the space group symmetry, from acentric orthorhombic $\mathrm{P} 2{ }_{1}$ ma (26) to orthorhombic Cmcm (63) and then to cubic Pm-3m (221). The symmetry improvement was already described for $\mathrm{NaNbO}_{3}$, with five phase transitions occuring between the RT phases mainly in the Pbma space group (57) and the high temperature cubic form, in addition to the low temperature 
rhombohedral phase. ${ }^{21,24,25,30}$ Interestingly, $\mathrm{Cmcm}$ and $\mathrm{Pm}-3 \mathrm{~m}$ stability domains are found at lower temperatures in $\mathrm{Ti}$ substituted species than in $\mathrm{NaNbO}_{3}$, with $\mathrm{Cmcm}$ symmetry observed from $300{ }^{\circ} \mathrm{C}$ instead of $550{ }^{\circ} \mathrm{C}$ and $\mathrm{Pm}-3 \mathrm{~m}$ from 600 ${ }^{\circ} \mathrm{C}$ instead of $670{ }^{\circ} \mathrm{C}$. This observation supports the trend of Ti substitution for $\mathrm{Nb}$ to tend to the cubic perovskite, in agreement with the Goldschmidt tolerance factor getting closer to 1. Moreover, the huge temperature difference observed for the $\mathrm{P} 2{ }_{1}$ ma-Cmcm phase-transition is attributed to the almost similar stability of the two $\mathrm{Na}$ sites and the four oxygen sites (Table 4) thanks to the $\mathrm{Ti}$ substitution for $\mathrm{Nb}$ and the creation of oxygen vacancies contributing to oxygen mobility. Further structural studies of the family $\mathrm{NaNb}_{1-\mathrm{x}} \mathrm{Ti}_{\mathrm{x}} \mathrm{O}_{3-0.5 \mathrm{x}}(0 \leq \mathrm{x} \leq 0.20)$ by powder neutron diffraction and high resolution XRD including synchrotron source should provide more accurate atomic positions, as investigated in previous works on $\mathrm{NaNbO}_{3}$ phase ${ }^{23}$, and temperatures for the polymorphic transitions. They allow distinguishing other phases that were not detected in this work.

Ionic conductivity. Dense pellets of $\mathrm{NaNb}_{1-\mathrm{x}} \mathrm{Ti}_{\mathrm{x}} \mathrm{O}_{3-0.5 \mathrm{x}}$ $(0 \leq x \leq 0.15)$ were obtained from powders synthetized in hydrothermal conditions, using the Spark Plasma Sintering (SPS) technique under primary vacuum of $10 \mathrm{~Pa}$. Briefly, a pressure of $100 \mathrm{MPa}$ was applied during the whole heat treatment, consisting in a ramp at $50{ }^{\circ} \mathrm{C} \cdot \mathrm{min}^{-1}$ up to $900{ }^{\circ} \mathrm{C}(\mathrm{x}=0)$ or $800{ }^{\circ} \mathrm{C}(\mathrm{x}=0.05,0.10$ and 0.15$)$. The dwell temperature was maintained during $5 \mathrm{~min}$ before the sample was left to cool below $100{ }^{\circ} \mathrm{C}$ in vacuum. The procedure is further detailed in the Experimental section. For $\mathrm{NaNb}_{0.90} \mathrm{Ti}_{0.10} \mathrm{O}_{2.95}$, after SPS at $800{ }^{\circ} \mathrm{C}$, the powder-XRD full-pattern profile matching (Figure 9, down) confirms the occurrence of a pure polar phase which crystallizes in the $\mathrm{P} 2{ }_{1}$ ma space group obtained from a mixture of RT polymorphs (initial powder in the inset). The gray-blue color of the pellet is attributed to inter-valence bands caused by the stabilization of $\mathrm{Nb}^{4+} / \mathrm{Ti}^{3+}\left(4 \mathrm{~d}^{1} / 3 \mathrm{~d}^{1}\right)$ species due to reductive conditions of the SPS experiments. ${ }^{29,53,54} \mathrm{~A}$ post-annealing treatment under air at $800{ }^{\circ} \mathrm{C}$ during $12 \mathrm{~h}$ fully re-oxidizes the reduced centers, as observed by a change of color from gray-blue to cream-white, whereas the structure is maintained, as shown by XRD in Figure 9, up. These results are general to $\mathrm{NaNb}_{1-\mathrm{x}} \mathrm{Ti}_{\mathrm{x}} \mathrm{O}_{3-0.5 \mathrm{x}}$ compositions $(\mathrm{x}=0.05,0.10$ and 0.15 ) with respective compactness of 93, 94 and $92 \%$ relatively to theoretical densities of the structures. Dimensions and weight of the pellet remained identical before and after the annealing treatment. In the case of $\mathrm{NaNbO}_{3}$, SPS sintering temperature of $900{ }^{\circ} \mathrm{C}$ was necessary to reach the similar relative density of $94 \%$. $\mathrm{NaNbO}_{3}$ crystallizes in the Pbma space group, as expected. ${ }^{29}$ The annealing treatment under air is an essential step preventing from electronic conduction in compounds with partially reduced niobium or titanium and thus allowing the study of pure ionic conduction properties.

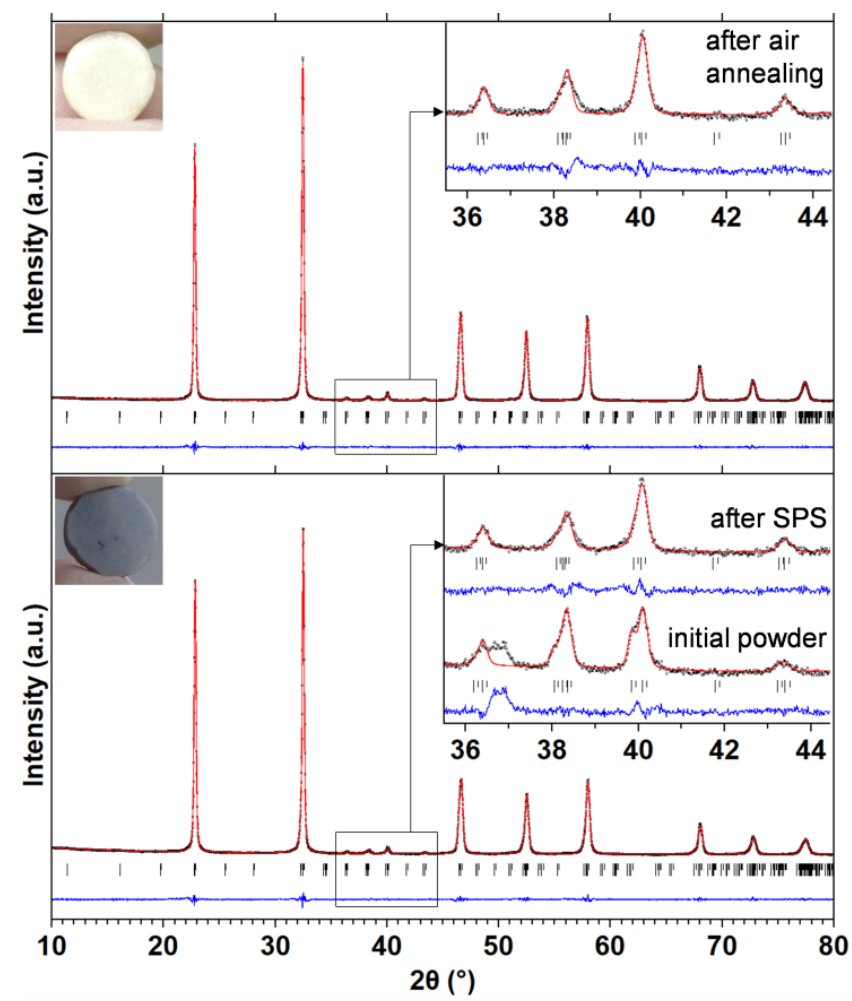

Figure 9. Powder XRD full-pattern profile matchings of $\mathrm{NaNb}_{0.90} \mathrm{Ti}_{0.10} \mathrm{O}_{2.95}$ complex oxide which adopts the $\mathrm{P} 2{ }_{1} \mathrm{ma}$ space group (down) after SPS at $800{ }^{\circ} \mathrm{C}$ during 5 min and (up) followed by annealing under air at $800{ }^{\circ} \mathrm{C}$ during $12 \mathrm{~h}$. Pictures of the pellet are also shown after SPS and after annealing, their diameter is ca. $10 \mathrm{~mm}$. Insets: zooms for $35.5^{\circ} \leq 2 \theta$ $\leq 44.5^{\circ}$ including XRD lines of the powder after hydrothermal synthesis (initial powder). (black crosses) experimental data, (red lines) calculated patterns and (blue lines) difference between observed and calculated data.

EIS meaurements were carried out on pellets densified by SPS and then heat treated under air (Figure S7).

A typical example of Nyquist plots measured at $313{ }^{\circ} \mathrm{C}$ of $\mathrm{NaNb}_{0.9} \mathrm{Ti}_{0.1} \mathrm{O}_{2.95}$ pellet with symmetrical platinum electrodes is reported on Figure S8. Experimental data has been fitted on the basis of an equivalent circuit constituted of R-CPE elements in parallel (Resistance-Constant Phase Element) associated in series. Each resistance R or CPE can be assigned to the resistance and capacitance associated to a specific electrochemical process. Usually one or two arcs more or less overlapped in the high frequency $(\mathrm{HF})$ range $\left(10^{6}-10^{4} \mathrm{~Hz}\right)$ and in the medium frequency $(\mathrm{MF})$ range $\left(10^{4}-1 \mathrm{~Hz}\right)$ appear. In the lower frequency $(\mathrm{LF})$ range $(1-0.01 \mathrm{~Hz})$, the electrode reaction occurs (Pt/air interface) and is modeled using the CPEtype impedance. In the present study, our attention is focused on the HF and MF contributions where the studied materials behavior is observed. On the basis of the fitted data, the relaxation frequency $\mathrm{f}_{\text {relax }}$ and the associated capacitive effect $\mathrm{C}_{\mathrm{eq}}$ of each $\mathrm{HF}$ and $\mathrm{MF}$ contributions are deduced using relations (A) and (B):

$$
f_{\text {relax }}=\frac{1}{2 \pi(R \times C P E)^{\frac{1}{n}}}
$$




$$
C_{e q}=R^{\left(\frac{1-n}{n}\right)} \times C P E^{\frac{1}{n}}
$$

where $f_{\text {relax }}, R$ and $C_{e q}$ are the frequency relaxation, the resistance and the equivalent capacitive effect respectively. CPE represents the modulus of the Constant Phase Element and $\mathrm{n}$ the depression parameter.

According to these impedance measurements, the bulk and grain boundaries conductivities have been reported in Arrhenius plots in the range $200-450^{\circ} \mathrm{C}$. The total conductivity of the sample have been deduced using to the relation: $\sigma=1$ $/\left(\mathrm{R}_{\text {bulk }}+\mathrm{R}_{\mathrm{gb}}\right) \times \mathrm{L} / \mathrm{S}$

For both contributions, the associated frequency relaxations and equivalent capacitive effect have been also reported in Figure S9. In the low temperature range, the impedance separation in two distinct contributions is possible. Nevertheless, for temperature higher than $450^{\circ} \mathrm{C}$, the overlap between grain boundaries and bulk impedance do not allow to well identify the different contribution. This phenomena can be assigned to the difference of the activation energies between bulk and grain boundaries $\left(\mathrm{E}_{\mathrm{A}}=0.47 \mathrm{eV}\right.$ and $0.59 \mathrm{eV}$ respectively). In the high temperature range, the total material impedance can be deduced by the impedance diagrams. The corresponding bulk dielectric constant has been estimated from the $C_{\text {Bulk }}$ value reported on Fig $S 9$ and $\varepsilon_{\mathrm{r}} \approx 800$ which is rather high.

The thermal evolution of their total ionic conductivity (Arrhenius plots) is shown in Figure 10. In the low temperature range, one should have to notice that the conductivity increases regularly with the $\mathrm{Ti}$ content. Especially, the ionic conductivity in $\mathrm{NaNb}_{0.85} \mathrm{Ti}_{0.15} \mathrm{O}_{2.925}$ phase varies linearly between $310^{-5}$ and $210^{-3} \mathrm{~S}^{-\mathrm{cm}^{-1}}$ in the studied interval $300<\mathrm{T}<700$ ${ }^{\circ} \mathrm{C}$. This is one to two orders of magnitude higher than in $\mathrm{NaNbO}_{3}$. This value must also be compared to the conductivity of $8 \%$ mol. yttria stabilized zirconia $\left(10^{-4}{\mathrm{~S} . \mathrm{cm}^{-1}}\right.$ at 400 $\left.{ }^{\circ} \mathrm{C}\right)^{55}$ and O-deficient perovskites $\mathrm{NaNb}_{0.5} \mathrm{Al}_{0.5} \mathrm{O}_{2.5}$, $\mathrm{NaTa}_{0.5} \mathrm{Al}_{0.5} \mathrm{O}_{2.5}, \mathrm{Na}_{0.5} \mathrm{Bi}_{0.49} \mathrm{TiO}_{2.985}$ and $\mathrm{Ba}_{3} \mathrm{MoNbO}_{8.5}\left(2.010^{-4}\right.$ $\left(1.510^{-3}\right), 210^{-4}\left(1.310^{-3}\right), 5.010^{-4}$ and $5.010^{-5}{\mathrm{~S} . \mathrm{cm}^{-1}}$ at $\mathrm{T}=$ $400{ }^{\circ} \mathrm{C}\left(700{ }^{\circ} \mathrm{C}\right)$ respectively) ${ }^{8-10}$ Similarly to the four previous compositions, the increase in the ionic conductivity is attributed to the increase of oxygen vacancies per unit, improving the anionic mobility. However, the use of niobiates as electrolyte in fuel cell should be problematic because in reduction condition, a few content of $\mathrm{Nb}^{4+}$ can be stabilized in perovskite network, then inducing electronic conductivity.

The stabilization of the P21ma polar phase versus Pbma space group after $\mathrm{Ti}$ substitution in sodium niobiate leads to lower the $(\mathrm{Nb}, \mathrm{Ti})_{\text {O6-y }}$ polyhedron distortion in the apical direction and consequently, due to competitive bonds, to increase the distortion in the equatorial plane. Starting with this specific $\left[\mathrm{Nb}^{5+} / \mathrm{Ti}^{4+} \mathrm{O}_{6-\mathrm{y}}\right]$ local environments associated with the second order Jahn-Teller effect $\left(4 \mathrm{~d}^{0} / 3 \mathrm{~d}^{0}\right)$ and the formation of oxygen vacancies, the oxygen mobility into this perovskite framework will be enhanced. Furthermore the phase transition from P21ma to Cmcm symmetry occurs at much lower temperature $\left(300^{\circ} \mathrm{C}\right.$ instead of $550^{\circ} \mathrm{C}$ in pure sodium niobiate) because of the almost similar crystallographic site stability of the two sodium and the four oxygen atomic positions which contribute to oxygen mobility and ionic conductivity. Finally Ti substitution for $\mathrm{Nb}$ allows to influence the steric effect as the Gold- schmidt factor tends to 1 with an easier access to more symmetric phase at higher temperatures $(\mathrm{Cmcm}$ and $\mathrm{Pm}-3 \mathrm{~m})$, to modify the sodium local environment and to increase the $\mathrm{d}$ orbitals crystal field splitting (electronic effects) associated to the formation of oxygen vacancies. These steric and electronic effects strongly affect the oxygen mobility and ionic conductivity.

To our knowledge, this is the first measurement of conductivity in Ti-substituted sodium niobates. The relatively high values reported here make them good candidates as new oxygen conductors in the $300^{\circ} \mathrm{C}$ to $700{ }^{\circ} \mathrm{C}$ intermediate temperature range ${ }^{56,57}$. It is worth noting that the slope of the thermal variation of the conductivity (Figure 10) do not change between $300^{\circ} \mathrm{C}$ and $700^{\circ} \mathrm{C}$ (from $\mathrm{Cmcm}$ to $\mathrm{Pm}-3 \mathrm{~m}$ space groups) whereas the slope of the thermal evolution of the reduced unitcell parameter (Figure 8) slightly evolves in this temperature range depending on the Ti content. Actually, the atomic positions and $\mathrm{Na} / \mathrm{Nb} / \mathrm{O}$ site stabilities (Madelung potentials) are very close in the two models $(\mathrm{Cmcm}$ and $\mathrm{Pm}-3 \mathrm{~m})$ and it is the reason why no drastic change of the conductivity between $300^{\circ} \mathrm{C}$ and $700^{\circ} \mathrm{C}$ is observed. Furthermore, the atomic site stabilities are close in the P21ma (almost similar Madelung potentials for the four oxygen sites as well as for the two sodium sites ) and $\mathrm{Cmcm}$ models (almost identical similar Madelung potentials for the three oxygen sites as well as for the two sodium sites, comparable to values obtained with $\mathrm{P} 21 \mathrm{ma}$ structural hypothesis). It is not the case for the Pbma space group (our previous work ${ }^{29}$ ) where oxygen site stabilities (Madelung potential calculation) are clearly different as well as the relative stability of the two sodium sites. Then, starting with the $\mathrm{P} 21 \mathrm{ma}$ network with highly distorted $(\mathrm{Nb} / \mathrm{Ti}) \mathrm{O}_{6}$ polyhedra and where the Madelung potential site stabilities are comparable to those of $\mathrm{Cmcm}$ model detected at $\mathrm{T}>300^{\circ} \mathrm{C}$, one should have to note that the starting polar phase P21ma should have an impact on the ionic conductivity and activation energy.

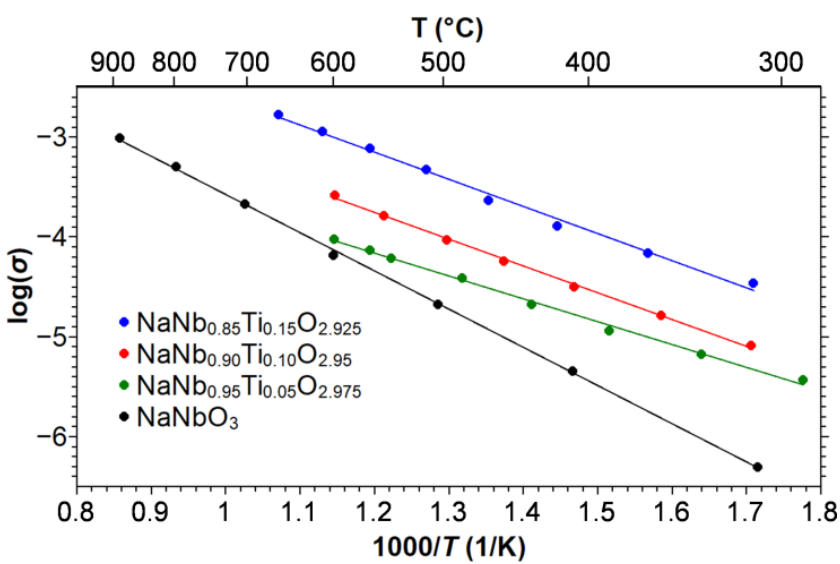

Figure 10. Total ionic conductivity of $\mathrm{NaNb}_{1-\mathrm{x}} \mathrm{Ti}_{\mathrm{x}} \mathrm{O}_{3-0.5 \mathrm{x}}(\mathrm{x}=0$, $0.05,0.10,0.15)$ in air.

Taking into account the as determined ionic conductivity and the concentration of oxygen vacancies $\mathrm{V}_{\mathrm{O}^{2}}$, the oxygenvacancy diffusion coefficient can be estimated around $10^{-8}$ $\mathrm{cm}^{2} / \mathrm{s}$ at $\mathrm{T}=400^{\circ} \mathrm{C}$ on the basis of the Nernst-Einstein formulae. This value is among the best oxygen ionic conductors mentioned in the literature ${ }^{58}$.

For each composition, total ionic conduction was considered as an activated process following the equation: 
$\log (\sigma T)=\log \left(\sigma_{0}\right)-\mathrm{E}_{\mathrm{a}} / \mathrm{R} T$

(1).

The activation energies $\mathrm{E}_{\mathrm{a}}$ for $\mathrm{x}=0.05,0.10$ and 0.15 were calculated from experimental data: $0.51,0.59$ and $0.60 \mathrm{eV}$, respectively. These values are quite similar to $\mathrm{NaNb}_{0.5} \mathrm{Al}_{0.5} \mathrm{O}_{2.5}$ and $\mathrm{NaTa}_{0.5} \mathrm{Al}_{0.5} \mathrm{O}_{2.5}(0.42 \text { and } 0.47 \mathrm{eV} \text {, respectively })^{10}$ and $\mathrm{Na}_{0.5} \mathrm{Bi}_{0.49} \mathrm{TiO}_{2.985}(0.4-0.5 \mathrm{eV})^{8}$, in good agreement with similar diffusion phenomena expected in O-deficient perovskitetype structures. The increase of the activation energy in this series should be due to the steric and electronic effects of $\mathrm{Ti}^{4+}$ $\left(3 d^{0}\right)$ which contribute to increase both the crystal field splitting and the $\mathrm{Nb}(\mathrm{Ti})-\mathrm{O}$ covalency, despite the increase of the second-order Jahn-Teller distortion mentioned above. The activation energy of $0.83 \mathrm{eV}$ for $\mathrm{NaNbO}_{3}$ is notably higher than for Ti substituted structures. This value can be assigned to a poor anionic conductor with low oxygen mobility due to the absence of structural anionic vacancy. ${ }^{55}$ The relatively high activation energy is also comparable to values found in various sodium conductors, such as phosphate $\mathrm{NaGe}_{2-\mathrm{x}} \mathrm{Ti}_{\mathrm{x}}\left(\mathrm{PO}_{4}\right)_{3}{ }^{59}$ and layered titanates ${ }^{14,15,60}$ and niobates. ${ }^{13}$ Additionally, Ruiz et al. found activation energies of $0.92 \mathrm{eV}$ for A-site deficient titanates $\mathrm{Na}_{3 \mathrm{x}} \mathrm{La}_{4 / 3-\mathrm{x}} \square_{2 / 3-\mathrm{x}} \mathrm{Ti}_{2} \mathrm{O}_{6}$. ${ }^{16}$ According to this article, the relatively high activation energies are attributed to steric effects on sodium mobility: conduction pathways between two neighboring A-sites are restricted by the narrow bottleneck formed by four adjacent $\left[\mathrm{TiO}_{6}\right]$ octahedra. Supposing that $\mathrm{Na}^{+}$ is the effective charge carrier in $\mathrm{NaNbO}_{3}$, the lower activation energy can be attributed to broader bottlenecks thanks to larger $\left[\mathrm{NbO}_{6}\right]$ octahedra. The nature of charge carrier is thus questioned in $\mathrm{NaNbO}_{3}$ with dual, though poor, ionic conducting properties. This issue will be addressed in future works. Furthermore, in order to go further, conductivity measurements on these samples should be performed under variable $\mathrm{P}_{\mathrm{O} 2}, \mathrm{P}_{\mathrm{H} 2 \mathrm{O}}$ (dry and wet condition) versus Temperature.

\section{CONCLUSIONS}

The combination of hydrothermal treatments in basic media ( $\mathrm{pH}=14$ ) at $\mathrm{T}=200{ }^{\circ} \mathrm{C}$ in autoclave, followed by annealing under air at high temperatures, from $\mathrm{T}=600^{\circ} \mathrm{C}$ to $950{ }^{\circ} \mathrm{C}$, allowed to prepare for the first time pure phases with $\mathrm{NaNb}_{1}$ ${ }_{\mathrm{x}} \mathrm{Ti}_{\mathrm{x}} \mathrm{O}_{3-0.5 \mathrm{x}}(\mathrm{x}=0.05,0.10,0.15)$ compositions. These complex oxides were shown to crystallize in the acentric P $2{ }_{1}$ ma space group and to be the most stable phase at RT, compared to the already known Pbma polymorph of $\mathrm{NaNbO}_{3}$. Two thermal phase transitions were also demonstrated to occur with an increase in space group symmetry from $\mathrm{P} 2{ }_{1}$ ma to $\mathrm{Cmcm}$ and then to Pm-3m. Such a polymorphism is shared with $\mathrm{NaNbO}_{3}$, but the transition temperature decreases drastically, especially for the first $\mathrm{P} 2{ }_{1} \mathrm{ma} \leftrightarrow \mathrm{Cmcm}$ transition. This variation should be due to the higher $\left[\mathrm{Nb}(\mathrm{Ti}) \mathrm{O}_{6}\right]$ polyhedron distortion, associated with second-order Jahn-Teller effect which induces a high oxygen mobility but also with the closest stability of the two $\mathrm{Na}$ sites as well as the four oxygen one's. Moreover, the surprising stability of structures in the $\mathrm{P} 2{ }_{1}$ ma space group is also explained by the transition metal polyhedron distortion which allows to stabilize oxygen vacancies in its vicinity and forces the two $\mathrm{Na}$ local environments to be almost identical by competitive bonds, with two acentric $\mathrm{Na}$ sites in $\mathrm{P} 2{ }_{1}$ ma network, while only one is acentric in Pbma symmetry, the other one being centrosymmetric. SPS confirmed the switch of relative stability between $\mathrm{P} 2{ }_{1}$ ma and Pbma space groups when Ti substitutes for $\mathrm{Nb}$. The optical band gaps variation estimated by diffuse reflectance measurements showed the decrease of the charge transfer energy for the lowest Ti content $(x=0.05)$ where the structural changes in the $\mathrm{NaNb}_{1-\mathrm{x}} \mathrm{Ti}_{\mathrm{x}} \mathrm{O}_{3-0.5 \mathrm{x}}$ series is the highest $(0 \leq x \leq 0.15)$. The distortion in the equatorial plane and the elongation in one apical direction after Tisubstitution illustrate the change of $\left[\mathrm{Nb}(\mathrm{Ti}) \mathrm{O}_{6}\right]$ polyhedra which probably contribute to increase the second-order JahnTeller effect and the crystal-field splitting. EIS measurements highlight the drastic increase of ionic conductivity with $\mathrm{Ti}$ content related to the improvement of oxygen mobility through introduction of $\mathrm{O}$ vacancies. Activated processes differ between $\mathrm{NaNbO}_{3}$ and $\mathrm{NaNb}_{1-\mathrm{x}} \mathrm{Ti}_{\mathrm{x}} \mathrm{O}_{3-0.5 \mathrm{x}}(\mathrm{x}>0)$. In the $\mathrm{NaNb}_{1-\mathrm{x}} \mathrm{Ti}_{\mathrm{x}} \mathrm{O}_{3-0.5 \mathrm{x}}(0 \leq \mathrm{x} \leq 0.15)$ series, $\mathrm{Na}^{+}$and $\mathrm{O}^{2-}$ are two candidates able to take charge of the ionic conduction. Future investigations on sodium niobiates with or without Ti substitution will assess the true nature of charge carriers taking charge of ionic conductivity.

The design of $\mathrm{Na}^{+}$blocking layers via sandwiched pellet (Yttria stabilized zirconia/ $\mathrm{NaNb}_{1-\mathrm{x}} \mathrm{Ti}_{\mathrm{x}} \mathrm{O}_{3-0.5 \mathrm{x}} /$ Yttria stabilized zirconia) sintered by Spark Plasma Sintering at high temperatures leads to quantified transport number of both ionic charge carriers $\mathrm{t}_{\mathrm{Na}+}$ and $\mathrm{t}_{\mathrm{O} 2-}$ (to be published). In the $400-700{ }^{\circ} \mathrm{C}$ temperature range, ionic conductivity can be tuned from major $\mathrm{Na}^{+}$contribution $\left(\mathrm{t}_{\mathrm{Na}+}=88 \%\right)$ for $\mathrm{NaNbO}_{3}$ to pure $\mathrm{O}^{2-}$ transport in $\mathrm{NaNb}_{0.90} \mathrm{Ti}_{0.10} \mathrm{O}_{2.95}$ phase. Such a Ti-substitution is accompanied with a ca. 100-fold increase in the oxygen conductivity, approaching best values for pure oxygen conductors in this temperature range.

\section{ASSOCIATED CONTENT}

\section{Supporting Information}

Supporting Information. The following file are available free of charge (Word document): Figure S1. Rietveld refinement of $\mathrm{NaNb}_{0.90} \mathrm{Ti}_{0.10} \mathrm{O}_{2.95}$ structure in the Pbma space group, after annealing at $950{ }^{\circ} \mathrm{C}$ during $24 \mathrm{~h}$; Table S1 Rietveld refinement of $\mathrm{NaNb}_{0.90} \mathrm{Ti}_{0.10} \mathrm{O}_{2.95}$ structure in the Pbma space group, after annealing at $950{ }^{\circ} \mathrm{C}$ during $24 \mathrm{~h}$; Figure S2. Profile matching of $\mathrm{NaNb}_{0.80} \mathrm{Ti}_{0.20} \mathrm{O}_{2.90}$ structure in the $\mathrm{P} 2{ }_{1}$ ma space group; Figure $\mathrm{S} 3$. Thermal polymorphism of $\mathrm{NaNb}_{0.95} \mathrm{Ti}_{0.05} \mathrm{O}_{2.975}$ and $\mathrm{NaNb}_{0.85} \mathrm{Ti}_{0.15} \mathrm{O}_{2.925}$; Figure $\mathrm{S} 4$. Rietveld refinements of $\mathrm{NaNb}_{0.90} \mathrm{Ti}_{0.10} \mathrm{O}_{2.95}$ XRD patterns acquired at 400 and $700{ }^{\circ} \mathrm{C}$. Figure S5 : XRD pattern of $\mathrm{NaNb}_{0.9} \mathrm{Ti}_{0.1} \mathrm{O}_{2.95}$ recorded at $\mathrm{T}=100$ ${ }^{\circ} \mathrm{C}$ with a Co $\mathrm{K} \alpha 1 / \mathrm{K} \alpha 2$ source $(\lambda=1.7890$ and $1.7919 \AA$, respectively) under helium. Figure S6: XRD pattern of $\mathrm{NaNb}_{0.9} \mathrm{Ti}_{0.1} \mathrm{O}_{2.95}$ recorded at $\mathrm{T}=300{ }^{\circ} \mathrm{C}$ with a Co $\mathrm{K} \alpha 1 / \mathrm{K} \alpha 2$ source $(\lambda=1.7890$ and $1.7919 \AA$, respectively) under helium. Figure S7. Nyquist diagrams of $\mathrm{NaNb}_{1-\mathrm{x}} \mathrm{Ti}_{\mathrm{x}} \mathrm{O}_{3-0.5 \mathrm{x}}(\mathrm{x}=0,0.05$, $0.10,0.15)$ from complex impedance spectroscopy. Figure S8: Typical impedance diagram obtained at $313^{\circ} \mathrm{C}$ $\left(\mathrm{NaNb}_{0.90} \mathrm{Ti}_{0.10} \mathrm{O}_{2.95}\right.$ pellet). Figure S9: a) Arrhenius plots of the conductivities of bulk and grain boundaries of $\mathrm{NaNb}_{0.9} \mathrm{Ti}_{0.9} \mathrm{O}_{2.95}$ pellet, deduced from impedance diagram (Figure S8) b) Arrheniius plots of the HF and MF relaxation frequencies for the different impedance contributions, c) associated $\mathrm{HF}$ and MF capacitive effects.

Powder XRD Rietveld data refinements of $\mathrm{NaNb}_{0.9} \mathrm{Ti}_{0.1} \mathrm{O}_{2.95}$ at room temperature, $\mathrm{T}=100^{\circ} \mathrm{C}, \mathrm{T}=300^{\circ} \mathrm{C}, 400^{\circ} \mathrm{C}$ and $700^{\circ} \mathrm{C}$ are available (.CIF files).

\section{AUTHOR INFORMATION}

\section{Corresponding Authors}


*(A.D.) alain.demourgues@icmcb.cnrs.fr and (G.G.) gougetg@sas.upenn.edu

\section{ORCID}

Alain Demourgues: 0000-0002-3828-8498

\section{Present Addresses}

$\dagger$ (G.G.) Department of Chemistry, University of Pennsylvania, Philadelphia, Pennsylvania 19104, United States.

\section{Author Contributions}

The manuscript was written through contributions of all authors. All authors have given approval to the final version of the manuscript.

\section{Funding}

The authors acknowledge the SOLVAY company for financial support.

\section{ACKNOWLEDGMENT}

The authors are grateful to Eric Lebraud for their help on the XRD experiments with temperature, as well as Dany Carlier for discussions on ${ }^{23} \mathrm{Na}$ NMR.

\section{REFERENCES}

(1) Stølen, S.; Bakken, E.; Mohn, C. E. Oxygen-Deficient Perovskites: Linking Structure, Energetics and Ion Transport. Phys. Chem. Chem. Phys. 2006, 8, 4, 429-447.

(2) Schaak, R. E.; Mallouk, T. E. Perovskites by Design: A Toolbox of Solid-State Reactions. Chem. Mater. 2002, 14, 14551471.

(3) Rondinelli, J. M.; Fennie, C. J. Octahedral Rotation-Induced Ferroelectricity in Cation Ordered Perovskites. Adv. Mater. 2012, 24 , 15, 1961-1968

(4) Kim, Y. M.; Kumar, A.; Hatt, A.; Morozovska, A. N.; Tselev, A.; Biegalski, M. D.; Ivanov, I.; Eliseev, E. A.; Pennycook, S. J.; Rondinelli, J. M.; Kalinin, S. V.; Borisevich, A. Y. Interplay of Octahedral Tilts and Polar Order in $\mathrm{BiFeO}_{3}$ Films. Adv. Mater. 2013, 25 , 17, 2497-2504.

(5) Balachandran, P. V.; Puggioni, D.; Rondinelli, J. M. CrystalChemistry Guidelines for Noncentrosymmetric $\mathrm{A}_{2} \mathrm{BO}_{4}$ RuddlesdenPopper Oxides. Inorg. Chem. 2014, 53, 1, 336-348.

(6) Kubicek, M.; Bork, A. H.; Rupp, J. L. M. Perovskite Oxides - a Review on a Versatile Material Class for Solar-to-Fuel Conversion Processes. J. Mater. Chem. A 2017, 5, 24, 11983-12000.

(7) Fujii, K.; Esaki, Y.; Omoto, K.; Yashima, M.; Hoshikawa, A.; Ishigaki, T.; Hester, J. R. New Perovskite-Related Structure Family of Oxide-Ion Conducting Materials $\mathrm{NdBaInO}_{4}$. Chem. Mater. 2014, 26 , 8, 2488-2491.

(8) Li, M.; Pietrowski, M. J.; De Souza, R. A.; Zhang, H.; Reaney, I. M.; Cook, S. N.; Kilner, J. A.; Sinclair, D. C. A Family of Oxide Ion Conductors Based on the Ferroelectric Perovskite $\mathrm{Na}_{0.5} \mathrm{Bi}_{0.5} \mathrm{TiO}_{3}$. Nat. Mater. 2014, 13, 1, 31-35.

(9) Fop, S.; Wildman, E. J.; Irvine, J. T. S.; Connor, P. A.; Skakle, J. M. S.; Ritter, C.; McLaughlin, A. C. Investigation of the Relationship between the Structure and Conductivity of the Novel Oxide Ionic Conductor $\mathrm{Ba}_{3} \mathrm{MoNbO}_{8.5}$. Chem. Mater. 2017, 29, 9, 4146-4152.

(10) Thangadurai, V.; Subbanna, G. N.; Shukla, A. K.; Gopalakrishnan, J. $\mathrm{AM}_{1-\mathrm{x}} \mathrm{Al}_{\mathrm{x}} \mathrm{O}_{3-\mathrm{x}}(\mathrm{A}=\mathrm{Na}$ or $\mathrm{K} ; \mathrm{M}=\mathrm{Nb}$ or Ta): New Anion-Deficient Perovskite Oxides Exhibiting Oxide Ion Conduction. Chem. Mater. 1996, 8, 95, 1302-1306.
(11) Singh, P.; Goodenough, J. B. $\mathrm{Sr}_{1-\mathrm{x}} \mathrm{K}_{\mathrm{x}} \mathrm{Si}_{1-\mathrm{y}} \mathrm{Ge}_{\mathrm{y}} \mathrm{O}_{3-0.5 \mathrm{x}}$ : A New Family of Superior Oxide-Ion Conductors. Energy Environ. Sci. 2012, $5,11,9626$

(12) Goodenough, J. B. Fast $\mathrm{Na}^{+}$-Ion Transport in Skeleton Structures. Mater. Reserch Bull. 1976, 11, 203-220.

(13) Sato, M.; Abo, J.; Jin, T.; Ohta, M. Structure and Ionic Conductivity of $\mathrm{MLaNb}_{2} \mathrm{O}_{7}(\mathrm{M} \equiv \mathrm{K}, \mathrm{Na}, \mathrm{Li}, \mathrm{H})$. J. Alloys Compd. 1993, $192,81-83$.

(14) Toda, K.; Kameo, Y.; Fujimoyo, M.; Sato, M. Crystal Structure and Ionic Conductivity of a Layered Perovskite, $\mathrm{Na}_{2} \mathrm{La}_{2} \mathrm{TiO}_{3} . J$. Ceram. Soc. Japan 1994, 102, 8, 737-741.

(15) Byeon, S.; Park, K. Structure and Ionic Conductivity of $\mathrm{NaLnTiO}_{4}$; Comparison with Those of $\mathrm{Na}_{2} \mathrm{Ln}_{2} \mathrm{Ti}_{3} \mathrm{O}_{10}(\mathrm{Ln}=\mathrm{La}, \mathrm{Nd}$, Sm, and Gd). J. Solid State Chem. 1996, 121, 430-436.

(16) Ruiz, A. I.; López, M. L.; Pico, C.; Veiga, M. L. New $\mathrm{La}_{2 / 3} \mathrm{TiO}_{3}$ Derivatives: Structure and Impedance Spectroscopy. $J$. Solid State Chem. 2002, 163, 472-478.

(17) Goldschmidt, V. M. Crystal Structure and Chemical Constitution. Trans. Faraday Soc. 1929, 253-283.

(18) Nadiri, A.; Flem, G. L. E.; Delmas, C. Lithium Intercalation in $\mathrm{Ln}_{1 / 3} \mathrm{NbO}_{3}$ Perovskite-Type Phases $(\mathrm{Ln}=\mathrm{La}, \mathrm{Nd})$. J. Solid State Chem. 1988, 73, 338-347.

(19) Mishchuk, D. O.; V, O. I.; Ovchar, O. V; Belous, A. G. Structural and Dielectric Properties of Solid Solutions of Sodium Niobate in Lanthanum and Neodymium Niobates. Inorg. Mater. 2004, 40, 12, $1508-1514$

(20) Belous, A. G.; Gavrilenko, O. N.; Kobilyanskaya, S. D.; Trachevskii, V. V. Effect of Isovalent Substitution on the Structure and Ionic Conductivity of $\mathrm{Li}_{0.5-\mathrm{y}} \mathrm{Na}_{\mathrm{y}} \mathrm{La}_{0.5} \square \mathrm{Nb}_{2} \mathrm{O}_{6}$. Inorg. Mater. 2011, $47,3,308-312$.

(21) Glazer, A. M.; Megaw, H. D. Studies of the Lattice Parameters and Domains in the Phase Transitions of $\mathrm{NaNbO}_{3}$. Acta Crystallogr. Sect. A 1973, 29, 5, 489-495.

(22) Ahtee, M.; Glazer, A. M. Lattice Parameters and Tilted Octahedra in Sodium-Potassium Niobate Solid Solutions. Acta Crystallogr. Sect. A 1976, 32, 434.

(23) Johnston, K. E.; Tang, C. C.; Parker, J. E.; Knight, K. S. Lightfoot, P.; Ashbrook, S. E. The Polar Phase of $\mathrm{NaNbO}_{3}$ : A Combined Study by Powder Diffraction, Solid-State NMR, and FirstPrinciples Calculations. J. Am. Chem. Soc. 2010, 132, 25, 8732-8746.

(24) Mishra, S. K.; Mittal, R.; Pomjakushin, V. Y.; Chaplot, S. L. Phase Stability and Structural Temperature Dependence in Sodium Niobate: A High-Resolution Powder Neutron Diffraction Study. Phys. Rev. B 2011, 83, 13, 134105.

(25) Peel, M. D.; Thompson, S. P.; Daoud-Aladine, A.; Ashbrook, S. E.; Lightfoot, P. New Twists on the Perovskite Theme: Crystal Structures of the Elusive Phases $\mathrm{R}$ and $\mathrm{S}$ of $\mathrm{NaNbO}_{3}$. Inorg. Chem. 2012, 51, 12, 6876-6889.

(26) Shannon, R. D. Revised Effective Ionic Radii and Systematic Studies of Interatomic Distances in Halides and Chaleogenides. Acta Crystallogr. Sect. A 1976, 32, 751-767.

(27) Xu, H.; Su, Y.; Balmer, M. Lou; Navrotsky, A. A New Series of Oxygen-Deficient Perovskites in the $\mathrm{NaTi}_{\mathrm{x}} \mathrm{Nb}_{1-\mathrm{x}} \mathrm{O}_{3-0.5 \mathrm{x}}$ System: Synthesis, Crystal Chemistry, and Energetics. Chem. Mater. 2003, 15 (9), 1872-1878.

(28) Goldschmidt, V. M. Die Gesetze Der Krystallochemie. Die Naturwissenschaften 1926, 14, 21, 477-485.

(29) Gouget, G.; Duttine, M.; Durand, E.; Villesuzanne, A.; Rodriguez, V.; Adamietz F.; Le Mercier, T.; Braida, M.-D.; Demourgues, A. Isolating the Two Room Temperature Polymorphs of $\mathrm{NaNbO}_{3}$ : Structural Features, Optical Band Gap and Reactivity. Just Accepted in ACS Applied Electronics Materials.

(30) Bondarev, V. S.; Kartashev, A. V; Gorev, M. V; Flerov, I. N.; Pogorel'tsev, E. I.; Molokeev, M. S.; Raevskaya, S. I.; Suzdalev, D. V; Raevskii, I. P. Thermal and Physical Properties of Sodium Niobate Ceramics over a Wide Temperature Range. Phys. Solid State 2013, $55,4,821-828$

(31) Shiratori, Y.; Magrez, A.; Fischer, W.; Pithan, C.; Waser, R.; Ju, D.-. Temperature-Induced Phase Transitions in Micro-, Submicro, and Nanocrystalline $\mathrm{NaNbO}_{3}$. J. Phys. Chem. C 2005, 109, 20122 20130. 
(32) Shiratori, Y.; Magrez, A.; Fischer, W.; Pithan, C.; Waser, R. Temperature-Induced Phase Transitions in Micro-, Submicro-, and Nanocrystalline $\mathrm{NaNbO}_{3}$. J. Phys. Chem. B 2007, 111, 18493-18502.

(33) Cai, B.; Schwarzkopf, J.; Hollmann, E.; Braun, D.; Schmidbauer, M.; Grellmann, T.; Wördenweber, R. Electronic Characterization of Polar Nanoregions in Relaxor-Type Ferroelectric $\mathrm{NaNbO}_{3}$ Films. Phys. Rev. B 2016, 93, 22, 1-8.

(34) Koruza, J.; Groszewicz, P.; Breitzke, H.; Buntkowsky, G.; Rojac, T.; Malič, B. Grain-Size-Induced Ferroelectricity in $\mathrm{NaNbO}_{3}$. Acta Mater. 2017, 126 (57), 77-85.

(35) Singh, S.; Khare, N. Electrically Tuned Photoelectrochemical Properties of Ferroelectric Nanostructure $\mathrm{NaNbO}_{3}$ Films. Appl. Phys. Lett. 2017, 110 (15), 152902.

(36) Chao, L.; Hou, Y.; Zheng, M.; Yue, Y.; Zhu, M. Macroscopic Ferroelectricity and Piezoelectricity in Nanostructured $\mathrm{NaNbO}_{3} \mathrm{Ce}$ ramics. Appl. Phys. Lett. 2017, 110, 122901.

(37) Li, P.; Ouyang, S.; Xi, G.; Kako, T.; Ye, J. The Effects of Crystal Structure and Electronic Structure on Photocatalytic $\mathrm{H}_{2}$ Evolution and $\mathrm{CO}_{2}$ Reduction over Two Phases of Perovskite-Structured $\mathrm{NaNbO}_{3}$. J. Phys. Chem. C 2012, 116, 7621-7628.

(38) Li, P.; Ouyang, S.; Zhang, Y.; Kako, T.; Ye, J. SurfaceCoordination-Induced Selective Synthesis of Cubic and Orthorhombic $\mathrm{NaNbO}_{3}$ and Their Photocatalytic Properties. J. Mater. Chem. A 2013 $1,4,1185-1191$

(39) Yu, Q.; Zhang, F.; Li, G.; Zhang, W. Preparation and Photocatalytic Activity of Triangular Pyramid $\mathrm{NaNbO}_{3}$. Appl. Catal. B: Environ. 2016, 199, 166-169.

(40) Wang, G. Z.; Chen, H.; Wu, G.; Kuang, A. L.; Yuan, H. K. Hybrid Density Functional Study on Mono- and Codoped $\mathrm{NaNbO}_{3}$ for Visible-Light Photocatalysis. ChemPhysChem 2016, 17, 489-499.

(41) Gu, L.; Zhou, D.; Cheng Cao, J. Piezoelectric Active Humidity Sensors Based on Lead-Free $\mathrm{NaNbO}_{3}$ Piezoelectric Nanofibers. Sensors 2016, 16, 883.

(42) Saito, Y.; Takao, H.; Tani, T.; Nonoyama, T.; Takatori, K.; Homma, T.; Nagaya, T.; Nakamu, M. Lead-Free Piezoceramics. Nature 2004, 432, 84-87.

(43) Rödel, J.; Webber, K. G.; Dittmer, R.; Jo, W.; Kimura, M.; Damjanovic, D. Transferring Lead-Free Piezoelectric Ceramics into Application. J. Eur. Ceram. Soc. 2015, 35, 6, 1659-1681.

(44) Peel, M. D.; Ashbrook, S. E.; Lightfoot, P. Unusual Phase Behavior in the Piezoelectric Perovskite System, $\mathrm{Li}_{x} \mathrm{Na}_{1-\mathrm{x}} \mathrm{NbO}_{3}$. Inorg. Chem. 2013, 52, 15, 8872-8880.

(45) Chang, K. B.; Vinokur, A.; Pinlac, R. A. F.; Suchomel, M. R.; Marvel, M. R.; Poeppelmeier, K. R. How Lewis Acidity of the Cationic Framework Affects $\mathrm{KNaNbOF}_{5}$ Polymorphism. Inorg. Chem. 2014, 53 13, 6979-6984.

(46) Chang, K. B.; Edwards, B. W.; Frazer, L.; Lenferink, E. J.; Stanev, T. K.; Stern, N. P.; Nino, J. C.; Poeppelmeier, K. R. Hydrothermal Crystal Growth, Piezoelectricity, and Triboluminescence of $\mathrm{KNaNbOF}_{5}$. J. Solid State Chem. 2016, 236, 78-82.
(47) Petrícek, V.; Dušek, M.; Palatinus, L. Crystallographic Computing System JANA2006: General Features. Zeitschrift fur Krist. 2014, 229, 5, 345-352.

(48) Massiot, D.; Fayon, F.; Capron, M.; King, I.; Le Calvé, S.; Alonso, B.; Durand, J.-O.; Bujoli, B.; Gan, Z.; Hoatson, G. Modelling One- and Two-Dimensional Solid-State NMR Spectra. Magn. Reson. Chem. 2002, 40 (1), 70-76.

(49) Handoko, A. D.; Goh, G. K. L. Hydrothermal Synthesis of Sodium Potassium Niobate Solid Solutions at $200{ }^{\circ} \mathrm{C}$. Green Chem. 2010, $12,4,680$.

(50) Johnston, K. E.; Griffin, J. M.; Walton, R. I.; Dawson, D. M.; Lightfoot, P.; Ashbrook, S. E. ${ }^{93} \mathrm{Nb}$ NMR and DFT Investigation of the Polymorphs of $\mathrm{NaNbO}_{3}$. Phys. Chem. Chem. Phys. 2011, 13, 16, 7565 .

(51) Hanna, J. V.; Pike, K. J.; Charpentier, T.; Kemp, T. F.; Smith, M. E.; Lucier, B. E. G.; Schurko, R. W.; Cahill, L. S. A. ${ }^{93} \mathrm{Nb}$ SolidState NMR and Density Functional Theory Study of Four- and SicCoordinate Niobate Systems. Chem. Eur. J. 2010, 16, 3222-3239.

(52) Ewald, P. P. Die Berechnung Optischer Und Elektrostatischer Gitterpotentiale. Ann. Phys. 1921, 369, 3, 253-287.

(53) Wada, T.; Tsuji, K.; Saito, T.; Matsuo, Y. Ferroelectric $\mathrm{NaNbO}_{3}$ Ceramics Fabricated by Spark Plasma Sintering. Jpn. J. Appl. Phys. 2003, 42, 6110-6114.

(54) Shigemi, A.; Wada, T. Enthalpy of Formation of Various Phases and Formation Energy of Point Defects in Perovskite-Type $\mathrm{NaNbO}_{3}$ by First-Principles Calculation. Jpn. J. Appl. Phys. 2004, 43 9B, 6793-6798.

(55) Kharton, V. V; Marques, F. M. B.; Atkinson, A. Transport properties of solid oxide electrolyte ceramics: a brief review. Solid State Ionics 2004, 174, 135-149.

(56) B.C. Steeleand A. Heinzel. Materials for fuel cells technologies. Nature, 2001, 414, 345-352

(57) A. Watanabe. Polymorphic transformation of $\delta-\mathrm{Bi}_{2} \mathrm{O}_{3}$ stabilized with $\mathrm{Ln}_{2} \mathrm{O}_{3}(\mathrm{Ln}=\mathrm{Sm}, \mathrm{Eu}, \mathrm{Gd}, \mathrm{Tb}$ and Dy) into a new phase with a C-type rare earth oxide-related sructure. Solid State Ionics 1995, 79, 84-88.

(58) De Souza. R.A.. Oxygen Diffusion $n \mathrm{SrTiO}_{3}$ and related perovskite oxides. Adv. Funct. Mater. 2015, 25, 1, 6326-6342.

(59) Winand, J.-M.; Rulmont, A.; Tarte, P. Nouvelles Solutions Solides $\mathrm{L}^{\mathrm{I}}\left(\mathrm{M}^{\mathrm{IV}}\right)_{2-\mathrm{x}}\left(\mathrm{N}^{\mathrm{IV}}\right)_{\mathrm{x}}\left(\mathrm{PO}_{4}\right)_{3}(\mathrm{~L}=\mathrm{Li}, \mathrm{Na} \mathrm{M}, \mathrm{N}=\mathrm{Ge}, \mathrm{Sn}, \mathrm{Ti}, \mathrm{Zr}, \mathrm{Hf})$ Synthèse et Etude Par Diffraction X et Conductivité Ionique. J. Solid State Chem. 1991, 93, 341-349.

(60) Toda, K.; Kameo, Y.; Kurita, S.; Sato, M. Crystal Structure Determination and Ionic Conductivity of Layered Perovskite Compounds $\mathrm{NaLnTiO}_{4}$ (Ln = Rare Earth). J. Alloys Compd. 1996, 234, 1, $19-25$. 


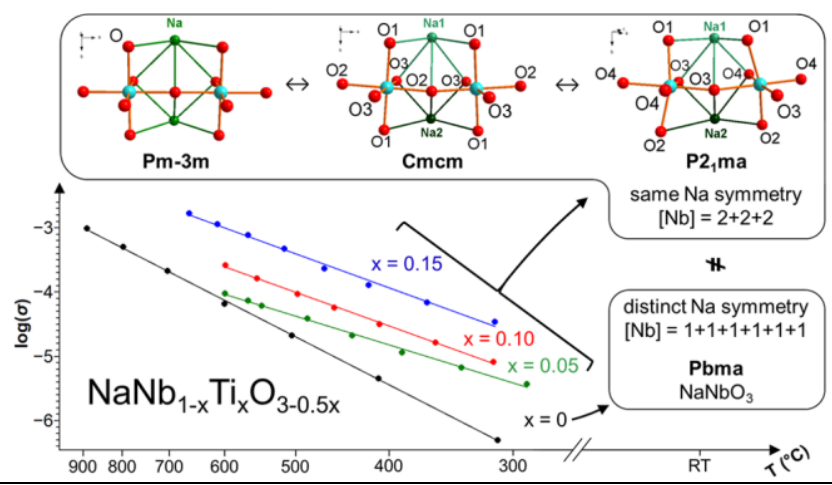

